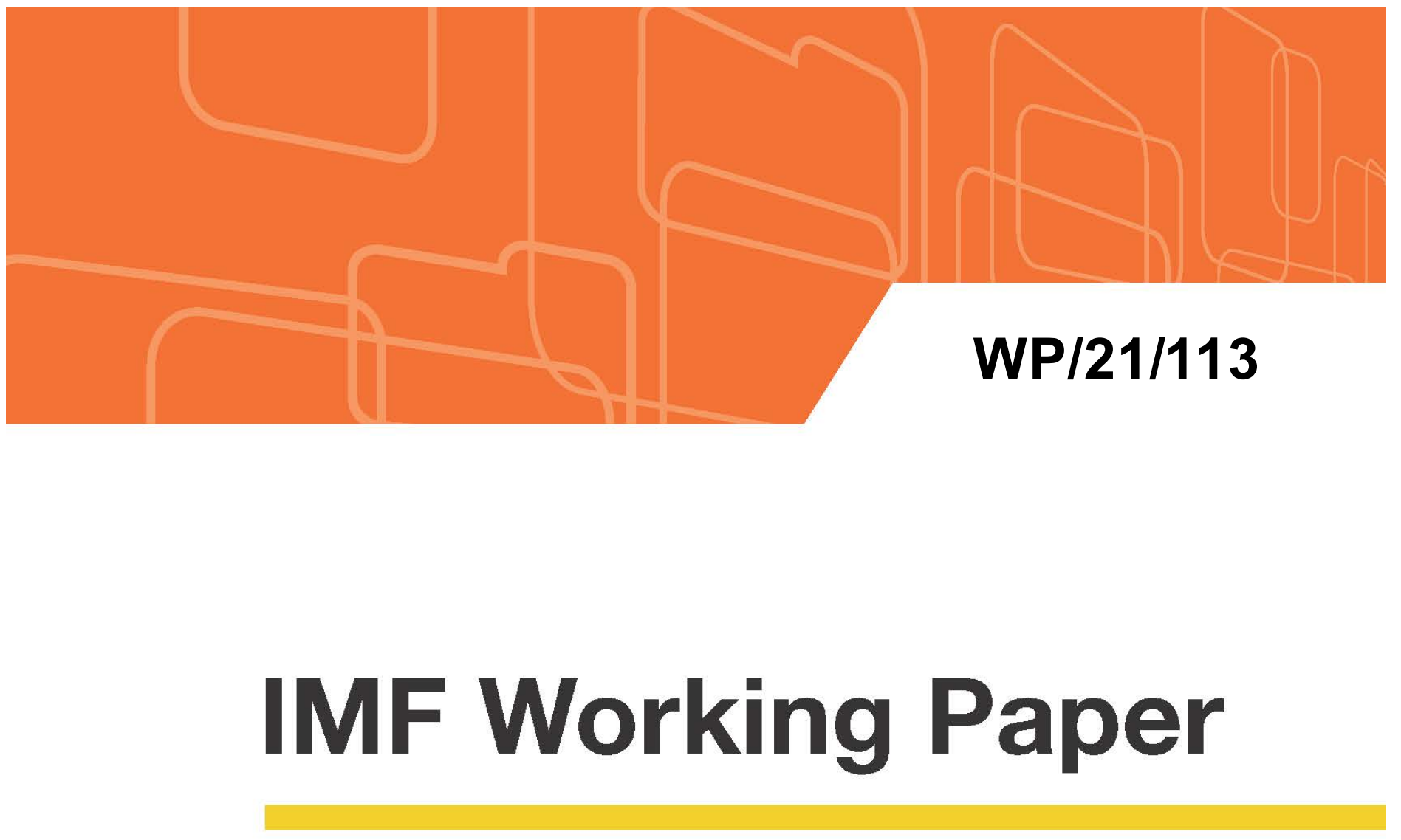

\title{
Leakages from Macroprudential Regulations: The Case of Household-Specific Tools and Corporate Credit
}

by Apoorv Bhargava, Lucyna Górnicka, and Peichu Xie

IMF Working Papers describe research in progress by the authors and are published to elicit comments and to encourage debate. The views expressed in IMF Working Papers are those of the authors and do not necessarily represent the views of the IMF, its Executive Board, or IMF management. 


\title{
IMF Working Paper
}

Monetary and Capital Markets Department

\section{Leakages from Macroprudential Regulations: The Case of Household-Specific Tools and Corporate Credit}

\author{
Prepared by Apoorv Bhargava, Lucyna Górnicka, and Peichu Xie ${ }^{1}$ \\ Authorized for distribution by Gaston Gelos
}

August 2021

\begin{abstract}
IMF Working Papers describe research in progress by the authors and are published to elicit comments and to encourage debate. The views expressed in IMF Working Papers are those of the authors and do not necessarily represent the views of the IMF, its Executive Board, or IMF management.
\end{abstract}

\begin{abstract}
Sector-specific macroprudential regulations can increase the riskiness of credit to other sectors. First, using cross-country bank-level data, we find that after a tightening of household-specific macroprudential policy during a credit expansion, banks with larger portfolios of residential mortgages increase their corporate lending by more than banks with smaller mortgage portfolios. Second, we compute three country-level measures of the riskiness of corporate credit allocation based on firm-level data. Consistently across the measures, an unexpected tightening of household-specific macroprudential tools during a credit expansion is followed by an increase in riskiness of corporate credit. These effects are quantitatively meaningful: the riskiness of corporate credit increases by around 10 percent of the historical standard deviation following an unexpected policy tightening. Further evidence from bank lending standards surveys suggests that the leakage effects are stronger for larger firms compared to SMEs, consistent with recent evidence on the use of personal real estate as loan collateral by small firms.
\end{abstract}

JEL Classification Numbers: G21, G28, G38

Keywords: Macroprudential regulations, leakages from financial regulations, sector-specific macroprudential tools, corporate credit risk, corporate loan growth.

Author's E-Mail Address: abhargava@imf.org, lgornicka@imf.org, xiepeichu@gmail.com

\footnotetext{
${ }^{1}$ We thank Viral Acharya, Katharina Bergant, Luis Brandão-Marques, Marco Casira ghi, Ga ston Gelos, Heedon Kang, Divya Kirti, Roland Meeks, Erlend Nier, Gurna in Pasricha, Jérôme Va ndenbussche, Wenyue Yang, seminar participants at the Bank of Lithuania, European Commission (EC), MCM Policy Forum(IMF), and conference participants at the $37^{\text {th }}$ Symposium on Money, Banking and Finance hosted by Banque de Fra nce for their comments and suggestions, a nd Sara Durrani for editoria la ssistance.
} 


\section{Introduction}

Macroprudential policies can have indirect effects on the economy that go beyond the direct impact on the lenders or borrowers they target. The literature on cross-border spillovers of financial regulations has documented that a tightening of regulations in the home country can lead to more and riskier lending by international banks in host countries (Houston et al. 2012, Ongena et al. 2013). In the macroprudential context, regulations limiting foreign-currency (FX) borrowing by banks lead to higher FX debt issuance by nonfinancial private corporations (Ahnert et al. 2020).

In this paper we provide evidence on another type of indirect effects of financial regulations: leakages from sector-specific macroprudential policies to borrowers in other sectors. Crosssectoral credit and risk substitution from macroprudential regulations can happen through various channels. For example, if lenders operate under fixed targets for aggregate returns or lending, or under fixed risk appetite, they could "compensate" a tightening of regulations in one loan segment by increasing targets in other segments. As a result, they could end up lending to borrowers that otherwise would be perceived as too risky (including through purchase of more risky securities). Alternatively, if a macroprudential action in one overheating sector leads to a perception of reduced risks in the economy, this could induce agents in other sectors to take on more risk. Bengui and Bianchi (2018) present a model where regulated agents reduce risktaking in response to taxes on excessive borrowing, but unregulated agents react to the safer environment by engaging in more risky activities.

From the policy perspective, estimates of such leakage and substitution effects could inform the choice between broad-based and targeted macroprudential tools. Yet, empirical evidence so far has been limited to few case studies (e.g. Auer and Ongena 2016, Acharya et al. 2020), making it difficult to generalize conclusions to a broader range of macroprudential policies. Our contribution is to fill this gap by providing evidence of leakages from sector-specific macroprudential tools across a large group of advanced and emerging economies, and by quantifying their magnitude ${ }^{1}$

Given their relatively broad adoption, we focus on macroprudential policies targeting borrowing by households, such as loan to income (LTI), loan to value (LTV) or debt service to income (DSTI) limits, and study the impact such measures can have on bank corporate lending volumes and on riskiness of corporate credit. First we demonstrate that as macroprudential regulations become tighter in the household sector, banks shift their lending to the corporates. Using bank-level balance sheet data for a range of countries, we show that after an unexpected

\footnotetext{
${ }^{1}$ By "leakages" we mean changes in credit to and in the risk profile of borrowers in the sectors that are not directly targeted by a macroprudential policy change. We do not distinguish here between intended and unintended effects. For example, a shift of risk from a sector with a high level of financial vulnerabilities to a sector where those vulnerabilities are contained, could be a desirable outcome from the perspective of policymakers at least in some instances.
} 
tightening of household-specific macroprudential measures during a credit expansion, banks with larger portfolios of residential mortgages experience much higher corporate loan growth compared to banks with smaller mortgage exposures.

Second, we show that the risk profile of corporate credit also increases after such unexpected tightening in household-specific macroprudential regulations. Using firm-level data for a range of economies, we construct three country-level measures of riskiness of corporate credit allocation that capture the relative riskiness of firms taking on a lot of new debt (both bank loans and market financing) compared to firms that do not increase their debt financing or increase it by very little. As shown in Greenwood and Hanson (2013), International Monetary Fund (2018) and in Brandão-Marques et al. (2019), measures based on the distribution of new borrowing among firms with different risk profiles predict i) performance of bond returns, ii) episodes of financial instability, and iii) downside risks to growth; they also signal a forthcoming crisis better than the underlying conventional corporate vulnerability indicators when considered individually.

Consistently across the three measures, we find that an unexpected tightening of householdspecific macroprudential tools increases the riskiness of corporate credit allocation in a country, but only during credit expansions 2 Quantitatively, corporate credit riskiness increases by 10 percent of a historical standard deviation when credit to GDP growth is one standard deviation above its sample mean. Is that a large effect? In the pre-GFC period of 2005-2008, which is known for rapid credit growth and build-up of financial vulnerabilities, the average year-onyear credit to GDP growth across countries stood at 14 percent (over 2.5 standard deviations above the sample mean), while the three riskiness measures increased during the same time by around 80 percent of the standard deviation, on average across countries. Thus, the leakages we document are considerable in magnitude. In fact, for the credit growth of 14 percent in the pre-GFC period, the size of spillovers from an unexpected household-specific macroprudential tightening would be 23 percent of historical standard deviation across the corporate credit riskiness measures (in the short-term).

The results are robust to controlling for domestic and global financial conditions, controlling for housing booms, excluding outliers, applying local projections, using pooled mean group estimation, using different definitions of macroprudential policies or looking at policy changes instead of policy shocks. Finally, when instead of the riskiness of corporate credit allocation we look at the changes in bank lending standards reported in loan officer surveys, we find that a tightening in the household-specific macroprudential policies is followed by a relaxation of lending standards for loans to large corporations, but by a tightening of lending standards for small- and medium-size enterprises (SMEs). The latter finding is consistent with the evidence that owners of SMEs oftentimes use personal real estate as collateral for firm loans (Adelino et

\footnotetext{
${ }^{2}$ Since macroprudential policies are often deployed in response to (or in order to prevent) increasing vulnerabilities, we derive macroprudential policy shocks following a procedure akin to Forbes and Klein (2015) and Ahnert et al. (2020), and use those in the baseline regressions.
} 
al. 2016, Bahaj et al. 2019).

Overall, our results point to economically meaningful leakages from sector-specific macroprudential tools to other sectors, both in terms of credit volume and its risk profile, but primarily during credit expansions. To demonstrate an economic mechanism consistent with these results, in Section 6 we present a simple model of bank portfolio choice. In the model, positive risk sentiment among investors or a positive signal about the economic outlook reduce bank funding costs and result in higher bank lending. As bank balance sheets expand, the regulatory capital requirements start to bind, generating interdependence between lending and the risk profile of loans in different loan segments.

In terms of policy implications, our results support policy interventions during the early phase of the credit expansion cycle, when vulnerabilities are growing but are still low and sectoral leakages are less important. They also point to the importance of timely monitoring of vulnerabilities and riskiness in both household and corporate sectors. For the corporate sector, information on the distribution of the loans in banks' corporate portfolios by firm size might be relevant for assessing the size of potential leakage effects. While an alternative way to address the leakages this paper identifies would be to design more macroprudential tools targeting firms, this has been challenging in practice due to heterogeneity of business models across firms.

The rest of the paper is structured as follows. Section 2 reviews the relevant literature. Section 3 describes the data sources and explains the construction of the corporate loan growth indicator, macroprudential policy indexes and the corporate riskiness indicators. Section 4 provides empirical evidence on the portfolio substitution by banks from residential sector to corporate sector. Section 5 documents that such credit allocation is riskier by presenting the results and further robustness checks. Section 6 introduces a simple model of bank portfolio choice to explain our key findings and Section 7 concludes.

\section{Literature}

Past research has primarily focused on the impact of macroprudential policies on credit and house price growth. Kuttner and Shim (2016) find that a tightening of DSTI limits lowers the housing credit growth rate, and that an increase in the housing-related taxes lowers both housing credit and house price growth. The results in Cerutti, Claessens and Laeven (2017) suggest that the use of macroprudential policies has significant mitigating effects on real credit growth, especially for emerging economies and economies with relatively closed capital accounts. They also suggest a higher effectiveness of these policies in the boom than in the bust phase of financial cycles and find evidence of cross-border borrowing as a potential channel of regulatory evasion. Akinci and Olmstead-Rumsey (2018) find that periods of macroprudential policy tightening are associated with slower bank credit growth, slower house credit growth and smaller house price appreciation. Additionally, household sector-specific policies like LTV and DSTI limits are 
more important for constraining house price appreciation when bank lending is an important source of credit. Alam et al. (2019) find that the effect of a tightening of LTV limits on household credit growth is non-linear in the size of the tightening and in the initial LTV limit level. Araujo et al. (2020) provide a metadata analysis of the findings across over 50 studies analyzing effectiveness of macroprudential policies.

Several papers have looked at leakages from macroprudential policies. Especially post-GFC, there has been substantial interest in arbitrage of domestic regulations through cross-border activities. Houston, Lin and Ma (2012) use a cross-country study to show that capital flows from markets with more restrictive regulations to markets with loose regulation. Ongena, Popov and Udell (2013) find that domestic banking regulations have significant spillovers through crossborder banking activities. Stricter domestic regulations result in lower lending standards in foreign markets, which are further lowered if the domestic supervision is inefficient. Aiyar, Calomiris and Wieladek (2014) provide evidence of regulatory arbitrage in the U.K., where regulatory tightening leads to a contraction in loan supply by domestic banks but to an expansion of loan supply by subsidiaries of foreign banks. Using bank-level data for the U.K., Danisewicz, Reinhardt and Sowerbutts (2017) show that increased capital requirements result in a contraction of international bank lending, and that this effect is amplified by unconventional policies aimed at bolstering domestic lending. Ahnert et al. (2020) find that although macroprudential FX regulations are effective in reducing foreign currency borrowing by banks, FX-related risks are partially shifted to the corporate sector through increased FX bond issuance. Temesvary (2018) finds that as host countries' regulations became more restrictive relative to the U.S. during 2003-2013, global U.S. banks substituted from lending through local affiliates in host countries to more direct cross-border lending.

The existing empirical evidence on the leakages from sector-specific macroprudential policies to other types of borrowers is limited to few case studies. For example, Auer and Ongena (2016) exploit variation in banks' exposure to the housing sector to study the impact that a countercyclical buffer against mortgage exposures introduced in Switzerland in 2012 had on banks' lending profiles. They find that banks with a higher share of residential risk-weighted assets relative to total assets lent more to corporations than banks with a lower share, and that banks shifted lending to riskier and smaller firms following the introduction of the buffer. Acharya et al. (2020) use supervisory loan-level and house price data from Ireland and find that banks more affected by the introduction of LTI and LTV limits on residential mortgages in 2015 increased their holdings of high-yield securities and increased lending to the corporate sector (at lower rates). For both papers, however, the case-specific character of the micro-level analysis raises questions whether conclusions from such studies can be generalized to other macroprudential policies.

Closely related to our analysis are a couple of papers. Cizel at al. (2019) find evidence of substitution of credit from banks towards the non-bank financial sector after macroprudential 
actions and document that this effect is stronger when the macroprudential policies are binding for banks. In comparison, our paper focuses on the riskiness of credit to corporates, and on portfolio substitution within the banking sector. Another work is by Ayyagari, Beck and Martinez-Peria (2018), who look at the effects of macroprudential policies by firm size and age. They find that borrower-based macroprudential tools slow down credit growth of corporates, but predominantly for micro firms, SMEs and young firms. In our analysis, we show that lending standards for SMEs tighten after a tightening of LTV, DSTI or other household-specific measures, but that the lending standards for loans to large corporates are eased 3

Finally, in constructing the measures of corporate credit riskiness, we build on the approach by Greenwood and Hanson (2013), International Monetary Fund (2018) and Brandão-Marques et al. (2019). Other papers on credit riskiness include Kirti (2020), who constructs a measure of lending standards based on primary debt capital markets data and finds it to closely follow survey measures of bank lending standards. We use bank lending surveys as a robustness check for our results.

\section{Data}

Measuring corporate loan growth using bank-level data. To identify the effects of macroprudential policy actions on banks' corporate lending volumes, we check whether changes in household-specific regulations have a differential impact on corporate loan growth depending on banks' exposure to the residential mortgage segment. For this purpose, we collect data on bank-level volumes of corporate and residential mortgage loans from Fitch Connect. We focus on data at annual frequency from 1998 to 2018, since it is more consistent and has better coverage compared to the data at quarterly frequency. The availability of information on residential mortgage lending and corporate lending limits our sample to 13 countries (Brazil, Canada, Chile, China, Finland, Germany, Malaysia, Mexico, Poland, Russia, Spain, Sweden and Thailand). The variable of interest is relative corporate loan growth (CLG), equal to the difference in the annual growth rates in the ratio of corporate loans to total (net) bank loans among the top 30 and bottom 30 percent of banks, when ranked according to the size of their residential mortgage portfolios (relative to total net loans) 4 We impose a condition of a minimum of 10 bank observations for each country-year and require that each bank has at least 6 years of data.

\footnotetext{
${ }^{3}$ One channel could be the use of personal real estate as collateral to finance small firms as in Gelos and Werner (2002) and Adelino, Schoar and Severino (2016). Lian and Ma (2020) show, for the U.S., that assetbased (collateralized) loans are more common among small and young firms, compared to large and old corporates who rely more on cash flow-based loans.

${ }^{4}$ Net loans are total loans net provisions. Corporate loans category covers loans and leases to corporate and commercial enterprises. These exclude non-residential and commercial property mortgage loans. Residential mortgage loans category covers loans secured by residential property and excludes unsecured loans or loans secured by assets other than residential property.
} 
Measuring corporate credit riskiness. We construct measures of riskiness of corporate credit allocation following Greenwood and Hanson (2013). Their key insight is that cyclical changes in the pricing of credit risk disproportionately affect financing costs faced by lowquality firms compared to high-quality firms. Thus, to the extent that firms issue more debt when it is cheap, the time-variation in debt issuer quality may be useful for monitoring financing conditions and credit vulnerabilities. Greenwood and Hanson (2013) measure the riskiness of corporate credit as the difference in the expected default frequency (EDF) between the top 20 percent of debt issuers among NYSE-listed firms and the bottom 20 percent of debt issuers among the listed firms and show that it is a more reliable signal of credit market overheating than rapid credit growth. This result holds also when using differences in leverage and the interest coverage ratio (ICR) among debt issuers instead of the EDF. Acharya et al. (2019) follow a similar approach, and measure riskiness using the ICR. International Monetary Fund (2018) analyze four measures of riskiness in the corporate sector: based on EDF, ICR, leverage, and using an indicator for debt overhang. Brandão-Marques et al. (2019) find these indicators predicting reversals of financial conditions and corporate spreads. Such measures combine features of a corporate financial vulnerability measure and of a risk sentiment measure.

Following this literature, we consider thre $5^{5}$ measures of riskiness of corporate credit allocation, based on three indicators of firm-level financial vulnerability:

- leverage-based measure (TDTA hereafter), constructed by calculating the difference in the ratio of total debt to total assets of top 20 percent debt issuers over the current quarter and the bottom 20 percent debt issuers among listed firms,

- debt overhang measure (TDtE), constructed as above, but using the ratio of total debt to earnings before interest, taxes, depreciation and amortization (EBITDA) instead of total debt to total assets ratio,

- interest coverage ratio measure (ICR), constructed as above but using the interest coverage ratio, defined as the ratio of interest expenses to EBITDA.

For each vulnerability indicator (TDTA, TDtE, ICR), each firm is assigned a value (from 1 to 10) according to the decile of the distribution of the indicator in a given quarter and the country of location. Next, the firms are sorted in a similar way according to the change in the net debt over the past year relative to past total assets. Debt includes both loans and bond financing. A riskiness of corporate credit allocation measure is computed as the difference in the average value of the vulnerability indicator for the top debt-takers (assigned values 9 or 10 for the change in net debt) and the average value of the vulnerability indicator for the bottom

\footnotetext{
${ }^{5}$ Since the indicator based on Expected Default Frequency(EDF) may be deemed problematic for countries with illiquid equity markets, we focus on three common accounting ratios: debt-to-assets (leverage) ratio, interest coverage ratio (ICR), and debt-to-EBITDA (TDtE) ratio.
} 
debt-takers (assigned values 1 and 2) ${ }^{6}$ It follows that the riskiness measures increase (decline) whenever the average vulnerability indicators increase more (increase less or decline) among top debt-takers relative to bottom debt-takers.

All firm-level data come from Datastream. We drop all firms classified as financial, insurance or public administration companies. When constructing the measures of riskiness, we impose a condition of a minimum of 30 firm observations in each quarter for each country 7 To remove composition effects resulting from reporting on a lower than quarterly frequency by some firms, we seasonally-adjust all the series. Following the above procedure, we construct the measures of riskiness of corporate credit allocation for 29 economies (13 advanced plus 16 emerging) on a quarterly frequency (Table 1 ) 8 The sample is unbalanced, with data for majority of economies going back until 2002.

Table (1) Riskiness of corporate credit allocation: Country sample.

\begin{tabular}{c|c} 
Advanced Economies & Emerging Markets and Developing Economies \\
\hline \hline Austria, Canada, Denmark, Finland & Argentina, Brazil, Bulgaria, Chile, \\
Germany, Israel, Italy, Japan, & China, Indonesia, South Korea, Malaysia, \\
Netherlands, Norway, Portugal, Spain, Sweden & Mexico, Peru, Philippines, Poland, \\
& Russia, Thailand, Turkey, Vietnam
\end{tabular}

The correlation between the three alternative measures is high (highest for ICR and TDtE given similar definitions), although it varies somewhat across countries (Table2). Figure1 shows time series of TDTA, TDtE and ICR based measures for two countries: Denmark and Mexico. After Sweden, Denmark is the country with second-lowest correlation between leverage-based and the TDtE and ICR measures (of 0.12), while Mexico has a relatively high correlation (of $0.81)$.

Table (2) Correlations between the riskiness of corporate credit allocation measures (crosscountry averages).

\begin{tabular}{r|rrr} 
& TDTA & TDtE & ICR \\
\hline \hline TDTA & 1 & & \\
TDtE & 0.5 & 1 & \\
ICR & 0.38 & 0.79 & 1
\end{tabular}

International Monetary Fund (2018) construct the above three measures also using Datastream data but on annual frequency, which allows them to expand the sample to mid-1990s. They find that an increase in the riskiness of credit allocation measures signals heightened downside risks to GDP growth and a higher probability of banking crises and banking sector

\footnotetext{
${ }^{6}$ Using deciles instead of raw values of vulnerability indicators minimizes the influence of outliers and prevents the possibility of picking up secular trends affecting the results.

${ }^{7}$ Country-level correlations between the riskiness measures constructed using the threshold of 30 firms and the riskiness measures constructed using a higher threshold of 40 firms do not fall below 0.95. Given this, we use the threshold of 30 as it increases somewhat the number of observations in the sample.

${ }^{8}$ For additional 8 countries we were able to construct biannual time series.
} 
Figure (1) Evolution of the riskiness of corporate credit allocation in Denmark and Mexico (quarterly frequency, seasonally adjusted, demeaned).

Denmark

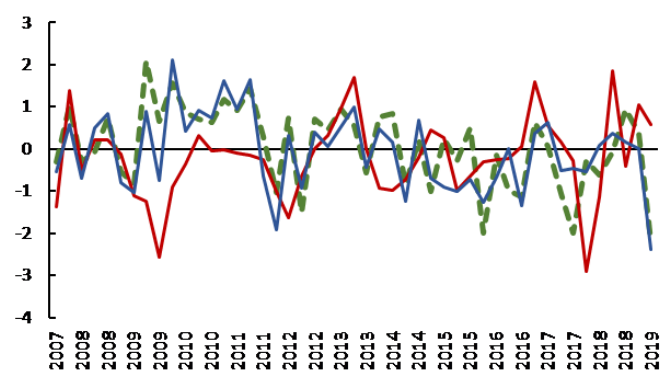

Mexico

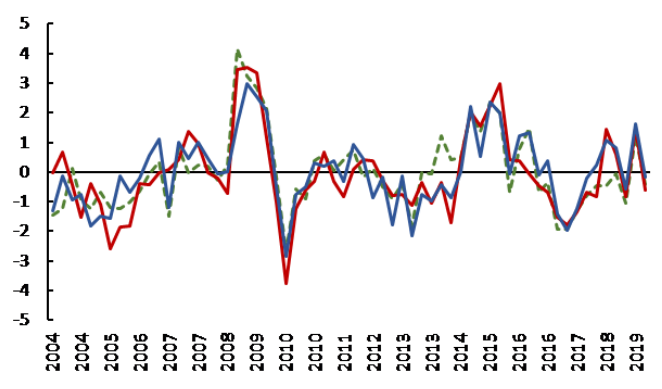

stress, over and above the previously documented signals provided by credit growth. Thus, a riskier allocation of corporate credit is an independent source of financial vulnerability.

Lending standards. As an additional robustness exercise, we use bank lending standards for corporate loans, as reported in bank loan officer surveys, instead of the corporate riskiness measures. Importantly, lending standards data can be further disaggregated into SMEs and large corporations, allowing us to estimate the leakage effects by the firm size 9 The data come from the ECB and national authorities and was collected through Haver Analytics and are available for 15 countries for which we also can construct macroprudential policy shocks (Austria, Canada, Germany, Italy, Japan, Korea, Netherlands, Norway, Philippines, Poland, Portugal, Russia, Spain, Thailand and Turkey) and goes back to 2002-2004 for most of the countries 10 The shortest time series are available for Thailand (2007Q4), Norway (2008Q1), Philippines (2009Q1), Russia (2009Q2). Given the considerable reduction in the sample size when using bank lending standards, we treat the three measures of the riskiness of corporate credit allocation as our baseline measures.

Macroprudential policies. We use the IMF iMaPP database as a source of information on macroprudential policy actions (MaPPs) ${ }^{11}$ The database reports macroprudential policy actions by the sector targeted by the measure (broad-based, household sector, corporate sector) on a quarterly frequency from mid-1990s until 2018Q4. Each policy change is recorded as +1 if it was a tightening action, and as -1 if it was an easing action. A zero is recorded if there was no policy change. We construct two MaPP policy indicators based on the iMaPP database:

- The household sector-targeting macroprudential policy actions indicator, $M a P P^{H H}$. We use the sum of changes in the four most widely used measures in literature, Loan to Value (LTV), Loan to Income (LTI), Debt to Income (DTI) and Debt Service to Income (DSTI) limits as our baseline measure. When conducting robustness exercises, we also use

\footnotetext{
${ }^{9}$ The criteria for a firm to be classified as a SME is not standardized and varies across countries.

${ }^{10}$ For Norway and Canada the surveys do not distinguish firms by size.

${ }^{11}$ See Alam et al. (2020) for a description of the database.
} 
a broader indicator, $M a P P^{H H}$ (Alternate), which is sum of changes in LTV, LTI, DTI, DSTI limits and restrictions on household loan characteristics.

- The broad-based plus corporate sector-specific macroprudential policy actions indicator, $M a P P^{B C}$. It includes changes in bank capital requirements (general and corporatespecific), changes in the countercyclical capital buffer, limits on credit growth (overall and corporate-specific) and restrictions on corporate loans characteristics. As a robustness check, we also use a narrower measure $M a P P^{B C}$ (Alternate), that captures changes in the countercyclical capital buffer, limits on credit growth (overall and corporate sector specific) and restrictions on corporate loan characteristics.

Overall, in the sample of 29 economies for which we were able to construct the riskiness of corporate credit allocation measures, we document 120 changes in baseline measures of householdspecific MaPPs, and 66 changes in baseline measures of the broad-based and corporate-specific MaPPs between 2002Q1-2018Q4. Importantly, there is little overlap between the two types of macroprudential interventions: changes in household-specific macroprudential measures are not highly correlated with changes in the broad-based or corporate-specific tools (Table 3 ).

Table (3) Number of macroprudential policy actions (easings or tightenings): 2002Q1-2018Q4 (29 countries).

\begin{tabular}{c|c|c|c} 
MaPP actions & \multicolumn{2}{|c|}{ Overlapping policy actions } & Total BC actions \\
& $H H$ (Baseline) & $H H$ (Alternate) & \\
\hline \hline & & 13 & 66 \\
$B C$ (Baseline) & 5 & 11 & 26 \\
$B C$ (Alternate) & 5 & 169 & -
\end{tabular}

Figure 2 shows that macroprudential policies have been used relatively more in EMs relative to AEs in our sample. For both types of MaPPs, the number of actions (tightening and easing) in EMs are almost double the number of actions in AEs. Separately, MaPP policies were tightened more often (154) as compared to eased (34) during the sample period. Moreover, householdspecific MaPPs were used more frequently than the broad-based or corporate-specific measures. Figure 3 shows the evolution of the policy actions in EMs and AEs by year. EMs tightened much more compared to advanced economies during the Global financial crisis period. 2018 saw a number of advanced economies tightening LTV and DSTI limits. 
Figure (2) Number of macroprudential policy changes between 2002Q1 and 2018Q4.

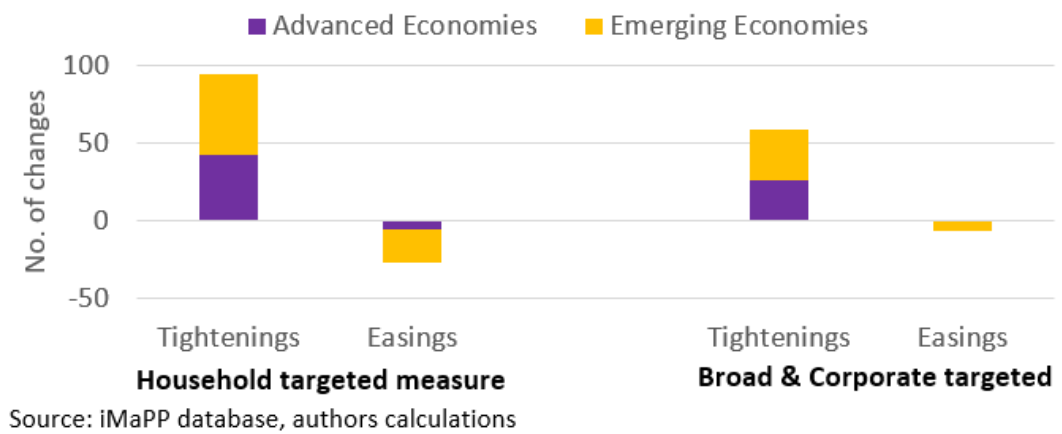

Figure (3) Use of macroprudential policies in advanced (top) and emerging economies (bottom).

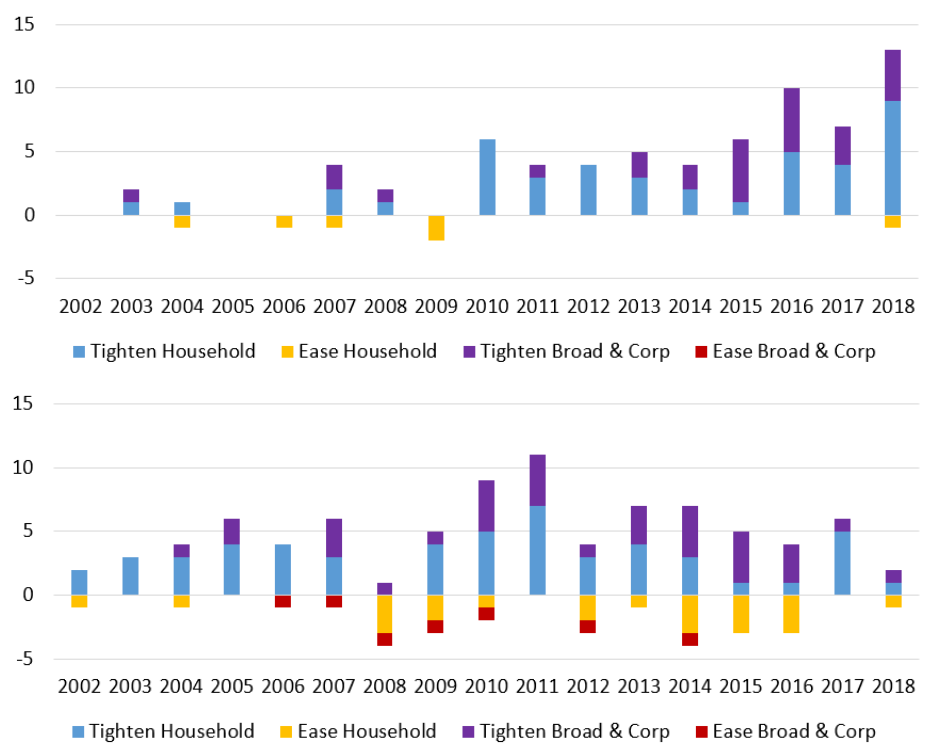

Macroprudential shocks. To address potential endogeneity issues, several papers studying macroprudential (or other financial) regulations consider shocks to macroprudential policy actions instead of actual policy changes. This is done by applying a two-stage regression procedure where policy functions for MaPPs are estimated first, and where the residuals from such regressions as used as the policy shocks (Forbes and Klein (2015), Ahnert et al. (2020) and Brandao-Marques et al. (2020)).

We expect that the endogeneity issues are less of a concern when considering leakages from macroprudential actions. This is because the decisions to ease or tighten household-specific macroprudential policies are likely to be taken independently of the situation in the corporate sector. Indeed, this is what the small overlap between household-specific and broad-based or corporate-specific MaPPs shown in the Table 3 seems to suggest. Nevertheless, a positive correlation between the corporate credit riskiness and the situation in the local household credit 
markets through the credit cycle is very likely. In this case, a tightening of household specific MaPPs in response to vulnerabilities building up e.g. in the housing market could spuriously show up as amplifying risks in the corporate sector as well. Thus, we follow the literature and use macroprudential policy shocks in our baseline regressions. In the Appendix A.5, we show the results are unchanged when using policy actions instead.

We obtain macroprudential shocks as residuals from ordered probit regressions of our indicator variables $M a P P^{H H}$ and $M a P P^{B C}$ on a range of macrofinancial variables: real GDP growth, one-year ahead GDP growth forecast, real credit growth, capital account openness, financial development index, exchange rate change against U.S. dollar, and real house price growth. Appendix A.2 describes the methodology for computation of shocks in detail and shows that the main results are robust to using an alternative specification of the ordered probit regression. The macroprudential shocks are available for a subsample of 24 out of 29 countries. The countries for which we cannot construct macroprudential shocks due to data constraints are Argentina, Bulgaria, Chile, Peru and Vietnam. We include those countries in the robustness regressions when we use macroprudential policy actions instead of policy shocks (Appendix A.5).

Other variables. We take GDP growth rates and exchange rates from WEO database. Data on credit to the private non-financial sector relative to GDP, on domestic corporate bond issuance and domestic bank credit to the corporate sector come from the BIS. The countryspecific financial conditions indices (FCI) are taken from the IMF 12 As an alternative measure of the domestic financial stance we use 3-month money market rates from Datastream. The global variables (MSCI VIX, U.S. policy rates) are from Datastream and Wu and Xia (2016). Data on GDP growth forecasts, financial development index, and capital account openness used in the first-stage regressions when deriving macroprudential policy shocks come from Consensus forecasts, IMF, and IMF's AREAER report, respectively. Table A1 in the Appendix A.1 lists all data sources.

\section{Leakages: Corporate Credit Growth}

\subsection{Empirical Strategy}

We apply panel regressions to study the impact of household-specific macroprudential policy changes on the growth of the volume of corporate lending by bank: 13 . The baseline regression specification takes the following form:

$$
C L G_{i, t}^{s}=\alpha+\beta_{1} \bar{\varepsilon}_{i, t}^{H H}+\beta_{2} \bar{\varepsilon}_{i, t}^{B C}+\beta_{3} \Delta \text { Credit }_{i, t}+\beta_{4} X_{i, t-1}+\delta_{i}+\delta_{t}+\epsilon_{i, t}
$$

\footnotetext{
${ }^{12}$ See International Monetary Fund (2017) and Koop and Korobilis (2014) for details.

${ }^{13}$ Given the relatively small sample size, we use standard OLS estimation. With both $\mathrm{N}$ and $\mathrm{T}$ small, the use of GMM estimation would provide biased estimates.
} 
where $C L G_{i, t}^{s}$ is a measure of relative growth of corporate loans to net loans in country $i$ in year $t$ and where $\bar{\varepsilon}_{i, t}^{H H}$ and $\bar{\varepsilon}_{i, t}^{B C}$ are macroprudential (household specific and broad-based or corporate specific) policy shocks in year $t$. A positive (negative) coefficient on a MaPP variable would suggest that an unexpected tightening of policy is associated with a larger increase (decline) in the share of corporate loans in loan portfolios of banks more exposed to residential mortgages compared to banks that have smaller exposures to residential mortgages. $\Delta$ Credit $_{i, t}$ is the year-on-year growth in the credit-to-GDP ratiq ${ }^{14}$ as a measure of the stance of the credit cycle. $X_{i, t-1}$ is a vector of control variables that includes year-on-year real GDP growth and domestic currency appreciation against U.S. dollar in the previous year (to control for changes from valuation changes in debt denominated in foreign currency). Finally, $\delta_{i}$ and $\delta_{t}$ denote time and country fixed effects. In all regressions we compute standard errors robust to heteroskedasticity and autocorrelation. Finally, since our dependent variable is available on annual frequency, we aggregate our macroprudential policy shocks to annual frequency as well 15

Past literature has documented that the effectiveness of the macroprudential policy likely depends on the position of the business and credit cycle (e.g. Cerutti et al. 2017, Araujo et al. 2020). To capture such nonlinear effects, we also consider an alternative specification, where the macroprudential policy shocks are interacted with the growth in the credit to GDP ratio.

$$
\begin{aligned}
C L G_{i, t}^{s} & =\alpha+\beta_{1} \bar{\varepsilon}_{i, t}^{H H}+\beta_{2} \bar{\varepsilon}_{i, t}^{H H} \times \Delta \text { Credit }_{i, t}+\beta_{3} \bar{\varepsilon}_{i, t}^{B C}+\beta_{4} \bar{\varepsilon}_{i, t}^{B C} \times \Delta \text { Credit }_{i, t}+ \\
& +\beta_{5} \Delta \text { Credit }_{i, t}+\beta_{6} X_{i, t-1}+\delta_{i}+\delta_{t}+\epsilon_{i, t}
\end{aligned}
$$

In the robustness checks, we consider additional controls: i) nominal short term market interest rates to account for domestic financial conditions, ii) real growth of bank credit to private nonfinancial corporations, and iii) the real growth of credit to households to make sure that the results are not just driven by the higher aggregate credit.

\subsection{Results and Robustness}

Column 1 of Table 4 shows the results from regression (1). Although the coefficient on the standalone household-specific MaPP shock is negative, it is statistically insignificant. At the same time, periods of high credit growth decrease the difference in growth of corporate loans among the banks most and least exposed to residential mortgages. In other words, banks with smaller residential mortgage portfolios experience higher corporate loan growth compared to banks with higher exposures to residential mortgages.

\footnotetext{
${ }^{14}$ Credit is measured as credit to the private non-financial sector and includes both domestic and cross-border credit flows. We do not distinguish between credit to the household sector versus corporates in order to maximize the number of countries in the sample (making this distinction would cut our sample by half). We also find household credit and corporate credit to be highly correlated with overall credit to the private non-financial sector.

${ }^{15}$ We do not consider the lagged dependent variable in the regressions as we do not expect an autoregressive nature of the relative corporate loan growth rates on an annual frequency.
} 
In Column 2 of Table 4, we add the interaction of the MaPP shocks and the credit growth as in equation (2), and in columns 3-6 we expand the specification with additional controls: domestic interest rates in Column 3, banks' corporate credit growth and household credit growth in Columns 4-6. We find that the standalone household-specific MaPP shocks are negatively associated with the dependent variable. In Columns 4-6, this term is statistically significant, implying that an unexpected tightening decreases the difference in corporate loan growth for banks with high and low exposure to residential mortgages. At the same time, consistently across Columns 2-6 in Table 4, we find that the interaction term of household-specific MaPP shocks and credit growth is positive and statistically significant, indicating the presence of a non-linear relationship. When credit growth is high, banks with larger residential mortgage portfolios experience higher corporate loan growth compared to banks which are less exposed to residential mortgages after an unexpected tightening of household MaPPs. This supports the narrative that the credit leakages to corporate sector are higher for banks more affected by the macroprudential regulations.

Quantitatively, when credit to GDP ratio grows at a rate of one standard deviation above the sample mean, the relative CLG increases by 54 percent of historical standard deviation. This shows that the portfolio re-allocation from residential mortgages to corporate loans following a household-specific MaPP tightening can be economically meaningful.

In Section 6, we consider a simple bank portfolio choice model to explain why leakage effects from macroprudential policies could be stronger during credit booms. In the model, a positive risk sentiment among investors reduces bank funding costs and results in higher bank lending. As bank balance sheets expand, the regulatory capital requirements start to bind, generating interdependence between lending and the risk profile of loans in different loan segments. Thus, the model predicts that both the riskiness of bank corporate lending and the volume of bank corporate loans increase during credit booms after a tightening of household-specific MaPPs. 
Table (4) Corporate Loan Growth Regressions

\begin{tabular}{|c|c|c|c|c|c|c|}
\hline & (1) & (2) & (3) & (4) & (5) & (6) \\
\hline VARIABLES & CLG & CLG & CLG & CLG & CLG & CLG \\
\hline \multirow[t]{2}{*}{$\bar{\varepsilon}_{t}^{H H}$} & -0.14 & -0.63 & -0.61 & $-1.22^{* *}$ & $-1.33^{*}$ & $-1.47^{*}$ \\
\hline & $(0.34)$ & $(0.48)$ & $(0.54)$ & $(0.53)$ & $(0.61)$ & $(0.67)$ \\
\hline \multirow[t]{2}{*}{$\bar{\varepsilon}_{t}^{B C}$} & 0.02 & -0.02 & 0.01 & 0.01 & -0.10 & -0.08 \\
\hline & $(0.62)$ & $(0.73)$ & $(0.75)$ & $(0.85)$ & $(0.90)$ & $(0.88)$ \\
\hline \multirow[t]{2}{*}{$\bar{\varepsilon}_{t}^{H H} \times \Delta$ Credit $_{t}$} & & $15.19^{* *}$ & $15.30^{*}$ & $20.51^{* *}$ & $22.80^{* *}$ & $23.56^{* *}$ \\
\hline & & $(6.51)$ & $(7.96)$ & $(8.61)$ & $(7.94)$ & $(8.29)$ \\
\hline \multirow{2}{*}{$\bar{\varepsilon}_{t}^{B C} \times \Delta$ Credit $_{t}$} & & 4.02 & 6.44 & 6.55 & 14.36 & $13.65^{*}$ \\
\hline & & $(7.12)$ & $(8.38)$ & $(9.44)$ & $(9.17)$ & $(7.31)$ \\
\hline \multirow{2}{*}{$N R_{t-1}$} & & & $-0.20^{* *}$ & & $-0.29^{* * *}$ & $-0.27^{* *}$ \\
\hline & & & $(0.08)$ & & $(0.09)$ & $(0.11)$ \\
\hline \multirow{2}{*}{$\Delta$ Credit $_{t}$} & $-10.41^{* *}$ & $-13.06^{* *}$ & $-13.87^{* *}$ & $-16.07^{*}$ & $-15.77^{*}$ & $-13.46^{* *}$ \\
\hline & $(3.43)$ & $(4.96)$ & $(4.77)$ & $(8.52)$ & $(7.72)$ & $(5.48)$ \\
\hline \multirow[t]{2}{*}{$\Delta G D P_{t-1}$} & 0.20 & 0.23 & 0.19 & $0.29^{*}$ & 0.22 & 0.22 \\
\hline & $(0.16)$ & $(0.16)$ & $(0.15)$ & $(0.16)$ & $(0.13)$ & $(0.16)$ \\
\hline \multirow[t]{2}{*}{$\Delta E R_{t-1}$} & -0.01 & -0.01 & 0.04 & $-0.01^{*}$ & 0.05 & 0.04 \\
\hline & $(0.01)$ & $(0.01)$ & $(0.03)$ & $(0.01)$ & $(0.03)$ & $(0.04)$ \\
\hline \multirow[t]{2}{*}{$\Delta$ BankCredit $_{t}$} & & & & 3.04 & 3.73 & \\
\hline & & & & $(7.61)$ & $(7.02)$ & \\
\hline \multirow[t]{2}{*}{$\Delta$ HouseholdCredit $_{t}$} & & & & & & 2.06 \\
\hline & & & & & & $(3.34)$ \\
\hline Observations & 132 & 132 & 123 & 111 & 102 & 102 \\
\hline Number of Countries & 13 & 13 & 12 & 12 & 11 & 11 \\
\hline Adjusted R-squared & 0.07 & 0.08 & 0.11 & 0.09 & 0.22 & 0.23 \\
\hline Interaction terms & No & Yes & Yes & Yes & Yes & Yes \\
\hline Country FE & Yes & Yes & Yes & Yes & Yes & Yes \\
\hline Time FE & Yes & Yes & Yes & Yes & Yes & Yes \\
\hline
\end{tabular}

Robust standard errors in parentheses

$* * * \mathrm{p}<0.01, * * \mathrm{p}<0.05, * \mathrm{p}<0.1$

Note: $\bar{\varepsilon}_{t}^{H H(B C)}$ is the household (broad and corporate specific) macroprudential policy shock, $\Delta C r e d i t$ is the growth of credit to non-financial private sector relative to GDP, $N R$ is the 3-month nominal domestic market interest rate, $\Delta E R$ is the rate of appreciation of local currency against USD, $\triangle G D P$ is the real GDP growth, $\Delta$ BankCredit is the real growth of credit to private nonfinancial corporations from banks, and $\Delta$ HouseholdCredit is the real growth of credit to households and NPISHs from all sectors 


\section{Leakages: Riskiness of Corporate Credit Allocation}

\subsection{Empirical Strategy}

To study the impact of household-specific macroprudential policy changes on the riskiness of corporate credit allocation, we use specification similar to (1)-2 in the previous section. The baseline regression takes the following form:

$$
C C_{i, t}^{s}=\alpha+\gamma C C_{i, t-1}^{s}+\sum_{k=1}^{4} \beta_{1, k} \varepsilon_{i, t-k}^{H H}+\sum_{k=1}^{4} \beta_{2, k} \varepsilon_{i, t-k}^{B C}+\beta_{3} X_{i, t-1}+\delta_{i}+\delta_{t}+\epsilon_{i, t},
$$

where $C C_{i, t}^{s}$ is a measure $s \in\{$ TDTA, TDtE, ICR $\}$ of corporate credit riskiness in country $i$ in quarter $t$ and where $\varepsilon_{i, t-k}^{H H}$ and $\varepsilon_{i, t-k}^{B C}$ are macroprudential (household specific and broad-based or corporate specific) policy shocks in quarter $t-k$. A positive (negative) coefficient on a MaPP variable would suggest that an unexpected tightening of policy is associated with an increase (decline) in the riskiness of corporate credit allocation. $X_{i, t-1}$ is a vector of control variables. In the baseline specification, it includes i) quarterly year-on-year growth in the credit-to-GDP ratio as a measure of the stance of the credit cycle, ii) quarterly year-on-year real GDP growth, iii) domestic currency appreciation against U.S. dollar in the previous quarter to control for changes in the riskiness of credit allocation from valuation changes in debt denominated in foreign currency. Finally, $\delta_{i}$ and $\delta_{t}$ denote time and country fixed effects. In all regressions we compute standard errors robust to heteroskedasticity and autocorrelation.

Similar to equation (2), we consider an alternative specification, where the macroprudential policy shocks are interacted with the growth in the credit to GDP ratio. To keep the model tractable and reduce the number of interaction terms, we include only one measure of macroprudential policy shocks, which is the sum of policy shocks in the past four quarters:

$$
\begin{aligned}
C C_{i, t}^{s} & =\alpha+\gamma C C_{i, t-1}^{s}+\beta_{1} \bar{\varepsilon}_{i, t-1}^{H H}+\beta_{2} \bar{\varepsilon}_{i, t-1}^{H H} \times \Delta \text { Credit }_{i, t-1}+ \\
& +\beta_{3} \bar{\varepsilon}_{i, t-1}^{B C}+\beta_{4} \bar{\varepsilon}_{i, t-1}^{B C} \times \Delta \text { redit }_{i, t-1}+\beta_{5} X_{i, t-1}+\delta_{i}+\delta_{t}+\epsilon_{i, t},
\end{aligned}
$$

where $\bar{\varepsilon}_{i, t}^{H H}=\sum_{k=0}^{3} \beta_{1, k} \varepsilon_{i, t-k}^{H H}, \bar{\varepsilon}_{i, t}^{B C}=\sum_{k=0}^{3} \beta_{1, k} \varepsilon_{i, t-k}^{B C}$, and where $\Delta C r e d i t_{i, t}$ stands for year-onyear growth in the credit-to-GDP ratio in country $i$ in quarter $t$.

\subsection{Baseline Results}

Before moving to our main results, we first demonstrate that household-specific macroprudential tools are effective in achieving their frequent operational targets i.e. affecting growth of credit to the household sector and growth of house prices. Table A4 in the Appendix shows that an unexpected household-specific MaPP tightening in the past four quarters reduces house price growth and growth of credit to the household sector when credit growth has been rapid 
in the recent past. This is consistent with past literature discussed in Section 2

Results from the baseline specification (3) are shown in columns 1-3 of Table 5 . The first lag of riskiness indicators is always positive and statistically significant, indicating high persistence of corporate credit riskiness. Among the control variables, the lag of growth of total credit to GDP is positive and highly significant, implying an increase in the riskiness of corporate credit allocation during credit expansions. GDP growth has a similar effect. Appreciation of the domestic currency against the US Dollar does results in a lower TDTA indicator, likely reflecting valuation effects from debt denominated in foreign currency. However, the opposite holds for the ICR indicator.

The first column of Table 5 shows the effect of an unexpected tightening of macroprudential measures on the leverage-based measure of corporate credit riskiness (TDTA). All lags of the household-specific MaPPs are positive, indicating that an unexpected tightening would be associated with an increase in riskiness of corporate credit allocation within a year. The coefficients on broad plus corporate sector-specific MaPP shocks have mixed signs, suggesting no clear association with corporate credit riskiness. However, the four lags of both types of MaPPs are not jointly statistically significant. Columns 2 and 3 of Table 5 show results for the other two riskiness indicators (ICR and TDtE), where the lags of MaPP shocks are again not statistically significant.

The lack of statistical significance of MaPP shocks in equation (3) could be due to missing non-linear effects of MaPPs depending on the stage of the credit cycle. In Section 6 we consider a simple theoretical framework that gives rise to such nonlinearities.

Columns 4-6 of Table 5 show the results of the alternative specification (4), where MaPP shocks are interacted with the credit to GDP growth. While the standalone MaPP terms continue to be insignificant (except for TDtE), the interaction term of the household-specific MaPP shock (in this case a sum of shocks in the past four quarters) with credit to GDP growth is positive and statistically significant for all three credit riskiness measures. Quantitatively, when the growth rate of credit to GDP ratio is equal to the sample average, an unexpected tightening in the household-specific MaPPs over the past year increases the riskiness of corporate credit allocation by about 1 percent of its historical standard deviation on average across measures. At the same time, when credit relative to GDP grows at a rate of one standard deviation above the sample mean, the impact on corporate credit riskiness is around 10 percent of historical standard deviation on average (Figure 4)-implying that the leakages from sector-specific MaPPs can be economically meaningful during credit expansions 16

Digging deeper into the magnitude of this effect, across the sample period from 2002Q1 to 2018Q4, we have 19 percent of the country-quarters with credit to GDP growth rate more

\footnotetext{
${ }^{16}$ As we show in Section 6, improved risk sentiment among bank creditors can lead to an expansion of bank balance sheets and result in binding regulatory requirements. Under these circumstances, banks' lending decisions in different loan segments become interdependent and a tightening of requirements for one loan type can affect the amount and the risk profile of loans in other loan segments.
} 
than one standard deviation above the sample mean (29 percent for the emerging economies and 10 percent of quarters for the advanced economies). Importantly, in the pre-GFC period 2005-2008-known for rapid credit growth and build-up of financial vulnerabilities-the average credit to GDP across countries stood at 14 percent, while the three riskiness measures increased during the same time by around 0.8 standard deviation over the same period, on average across countries. Thus, the leakages we document are considerable in magnitude. In fact, for the credit growth of 14 percent in the pre-GFC period, the size of direct (short-term) spillovers from an unexpected household-specific MaPP tightening would be 23 percent of historical standard deviation across the corporate credit riskiness measures.

Figure (4) Estimated impact of an unexpected tightening of household-specific MaPPs on corporate credit riskiness during credit expansion

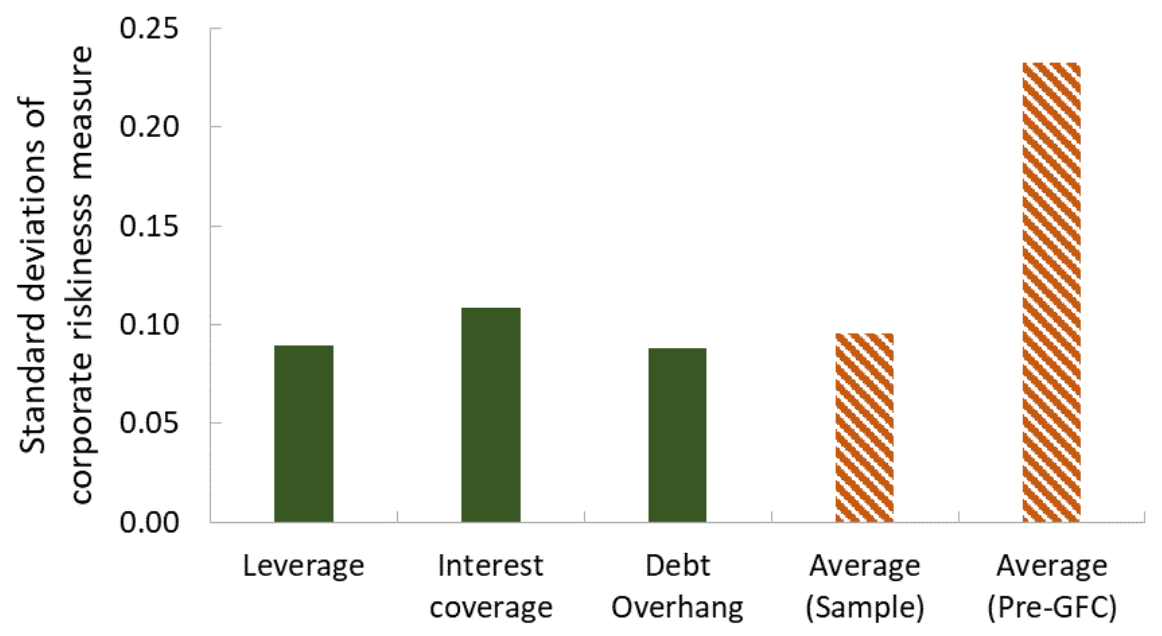

Note: Green bars measure the impact of a household-specific macroprudential tightening on each of the three corporate riskiness measures when credit growth is 1 standard deviation above its mean. Bars with orange stripes represent the average impact across these measures for the full sample period and, as a reference, the implied impact during the pre-GFC period.

The average long-run effect of an unexpected tightening in the household-specific MaPPs on corporate credit riskiness when credit relative to GDP grows at a rate of one standard deviation above the sample mean is around 16 percent of the standard deviation across the three measures (17 percent for TDTA, 16 percent for the ICR and 14 percent for TDtE measures, respectively).

The interaction term of the broad-based or corporate sector-specific MaPP shock with credit to GDP growth, while negative across measures, is statistically significant for the TDTA measure only. This result suggests that the effectiveness of those MaPP measures in reducing riskiness of credit in the corporate sector might be limited-perhaps thanks to the easier access to less regulated (non-bank) sources of funding for corporates compared to households. 
Table (5) Baseline Regressions

\begin{tabular}{|c|c|c|c|c|c|c|}
\hline VARIABLES & $\begin{array}{c}(1) \\
\text { TDTA }\end{array}$ & $\begin{array}{c}(2) \\
\text { ICR }\end{array}$ & $\begin{array}{c}(3) \\
\text { TDtE }\end{array}$ & $\begin{array}{c}(4) \\
\text { TDTA }\end{array}$ & $\begin{array}{l}(5) \\
\text { ICR }\end{array}$ & $\begin{array}{c}(6) \\
\text { TDtE }\end{array}$ \\
\hline DependentVariable $e_{t-1}$ & $\begin{array}{c}0.486^{* * *} \\
(0.042)\end{array}$ & $\begin{array}{c}0.328^{* * *} \\
(0.040)\end{array}$ & $\begin{array}{c}0.385^{* * *} \\
(0.037)\end{array}$ & $\begin{array}{c}0.487^{* * *} \\
(0.043)\end{array}$ & $\begin{array}{c}0.326^{* * *} \\
(0.040)\end{array}$ & $\begin{array}{c}0.381^{* * *} \\
(0.037)\end{array}$ \\
\hline$\varepsilon^{H H}$, Lag 1 & $\begin{array}{c}0.004 \\
(0.041)\end{array}$ & $\begin{array}{l}-0.061 \\
(0.044)\end{array}$ & $\begin{array}{l}-0.061 \\
(0.047)\end{array}$ & & & \\
\hline$\varepsilon^{H H}, \operatorname{Lag} 2$ & $\begin{array}{c}0.057 \\
(0.044)\end{array}$ & $\begin{array}{c}0.008 \\
(0.046)\end{array}$ & $\begin{array}{l}-0.044 \\
(0.050)\end{array}$ & & & \\
\hline$\varepsilon^{H H}, \operatorname{Lag} 3$ & $\begin{array}{c}0.116^{* *} \\
(0.044)\end{array}$ & $\begin{array}{l}-0.012 \\
(0.069)\end{array}$ & $\begin{array}{l}-0.023 \\
(0.057)\end{array}$ & & & \\
\hline$\varepsilon^{H H}, \operatorname{Lag} 4$ & $\begin{array}{c}0.004 \\
(0.045)\end{array}$ & $\begin{array}{c}0.064 \\
(0.044)\end{array}$ & $\begin{array}{c}0.062 \\
(0.054)\end{array}$ & & & \\
\hline$\varepsilon^{B C}, \operatorname{Lag} 1$ & $\begin{array}{c}0.064 \\
(0.122)\end{array}$ & $\begin{array}{c}0.087 \\
(0.117)\end{array}$ & $\begin{array}{c}0.113 \\
(0.157)\end{array}$ & & & \\
\hline$\varepsilon^{B C}, \operatorname{Lag} 2$ & $\begin{array}{c}0.096 \\
(0.110)\end{array}$ & $\begin{array}{c}0.004 \\
(0.112)\end{array}$ & $\begin{array}{c}0.058 \\
(0.137)\end{array}$ & & & \\
\hline$\varepsilon^{B C}, \operatorname{Lag} 3$ & $\begin{array}{l}-0.118 \\
(0.119)\end{array}$ & $\begin{array}{l}-0.080 \\
(0.128)\end{array}$ & $\begin{array}{l}-0.000 \\
(0.135)\end{array}$ & & & \\
\hline$\varepsilon^{B C}, \operatorname{Lag} 4$ & $\begin{array}{l}-0.102 \\
(0.097)\end{array}$ & $\begin{array}{l}-0.156 \\
(0.133)\end{array}$ & $\begin{array}{l}-0.193 \\
(0.134)\end{array}$ & & & \\
\hline $\bar{\varepsilon}_{t-1}^{H H}$ & & & & $\begin{array}{c}0.020 \\
(0.024)\end{array}$ & $\begin{array}{l}-0.029 \\
(0.032)\end{array}$ & $\begin{array}{c}-0.067^{*} \\
(0.038)\end{array}$ \\
\hline $\bar{\varepsilon}_{t-1}^{B C}$ & & & & $\begin{array}{c}0.026 \\
(0.045)\end{array}$ & $\begin{array}{c}0.019 \\
(0.065)\end{array}$ & $\begin{array}{c}0.023 \\
(0.078)\end{array}$ \\
\hline $\bar{\varepsilon}_{t-1}^{H H} \times \Delta$ Credit $_{t-1}$ & & & & $\begin{array}{c}0.012^{* *} \\
(0.005)\end{array}$ & $\begin{array}{l}0.014^{*} \\
(0.007)\end{array}$ & $\begin{array}{c}0.022^{* *} \\
(0.008)\end{array}$ \\
\hline $\bar{\varepsilon}_{t-1}^{B C} \times \Delta$ Credit $t_{t-1}$ & & & & $\begin{array}{c}-0.018^{*} \\
(0.010)\end{array}$ & $\begin{array}{l}-0.022 \\
(0.019)\end{array}$ & $\begin{array}{l}-0.015 \\
(0.014)\end{array}$ \\
\hline$\Delta$ Credit $_{t-1}$ & $\begin{array}{c}0.021^{* * *} \\
(0.005)\end{array}$ & $\begin{array}{c}0.025^{* * *} \\
(0.008)\end{array}$ & $\begin{array}{c}0.032^{* * *} \\
(0.007)\end{array}$ & $\begin{array}{c}0.019^{* * *} \\
(0.006)\end{array}$ & $\begin{array}{c}0.022^{* *} \\
(0.009)\end{array}$ & $\begin{array}{c}0.028^{* * *} \\
(0.008)\end{array}$ \\
\hline$\Delta G D P_{t-1}$ & $\begin{array}{c}0.044^{* * *} \\
(0.010)\end{array}$ & $\begin{array}{c}0.034^{* * *} \\
(0.012)\end{array}$ & $\begin{array}{c}0.057^{* * *} \\
(0.015)\end{array}$ & $\begin{array}{c}0.041^{* * *} \\
(0.010)\end{array}$ & $\begin{array}{c}0.031^{* *} \\
(0.012)\end{array}$ & $\begin{array}{c}0.055^{* * *} \\
(0.015)\end{array}$ \\
\hline$\Delta_{q} E R_{t-1}$ & $\begin{array}{c}-0.011^{*} \\
(0.005)\end{array}$ & $\begin{array}{l}0.013^{*} \\
(0.006)\end{array}$ & $\begin{array}{c}0.009 \\
(0.006)\end{array}$ & $\begin{array}{c}-0.011^{* *} \\
(0.006)\end{array}$ & $\begin{array}{l}0.012^{*} \\
(0.006)\end{array}$ & $\begin{array}{c}0.008 \\
(0.006)\end{array}$ \\
\hline Observations & 1,257 & 1,257 & 1,247 & 1,257 & 1,257 & 1,247 \\
\hline Number of Countries & 24 & 24 & 24 & 24 & 24 & 24 \\
\hline Adjusted R-squared & 0.379 & 0.169 & 0.251 & 0.381 & 0.173 & 0.254 \\
\hline Country FE & Yes & Yes & Yes & Yes & Yes & Yes \\
\hline Time FE & Yes & Yes & Yes & Yes & Yes & Yes \\
\hline Interaction & & & & Yes & Yes & Yes \\
\hline
\end{tabular}

Robust standard errors in parentheses

*** $\mathrm{p}<0.01,{ }^{* *} \mathrm{p}<0.05,{ }^{*} \mathrm{p}<0.1$

Note: $\varepsilon^{H H(B C)}$ is the household-specific (broad-based or corporate-specific) MaPP shock, $\bar{\varepsilon}_{t-1}^{H(B C)}$ is the sum of shocks in the past four quarters, $\Delta$ Credit $_{t-1}$ is the lagged yoy growth of credit to non-financial private sector relative to GDP, $\triangle G D P_{t-1}$ is the lagged yoy Real GDP growth, $\Delta_{q} E R_{t-1}$ is the lagged qoq local currency appreciation rate against USD. 


\subsection{Robustness}

We conduct a broad range of robustness exercises. Tables 648 present a sample of them, for each of the three credit riskiness measures. Our starting point is the specification (4) that includes the interaction term between the macroprudential variables and the growth rate of the credit to GDP ratio.

Column 1 in Tables 648 shows the results when controlling for the domestic financial conditions index (FCI). Across all three measures, the lag of the FCI has a negative sign and is statistically significant implying, in line with expectations that tighter financial conditions are associated with less risky corporate credit allocation. Importantly, the interaction terms with the growth in credit to GDP ratio remain positive and statistically significant. The results are unchanged when we use the 3-month money market rates or domestic corporate spreads (not shown) instead of the FCI, and when we include global financial variables (VIX index and the federal funds rate) instead of time fixed effects (column 2 in Tables 6 6).

A potential drawback of our approach is that our measures of riskiness of corporate credit allocation do not distinguish between bank versus bond credit, while the majority of the macroprudential policy measures affect bank lending only. There are, however, several channels through which household-specific MaPPs binding for banks only, could affect non-bank corporate credit. For example, as discussed in Bengui and Bianchi (2019), a perception of reduced risks in the economy as a result of macroprudential action in the household sector could induce agents in other sectors to take on more risk. Additionally, in response to limited lending opportunities in the retail segment, banks could begin to compete more aggressively in the market for corporate credit, contributing to lowering of credit standards for corporate bonds as well. Nevertheless, one could expect the impact of macroprudential measures, including any leakages from household-specific measures, on corporate credit riskiness to be smaller in countries where the corporate sector relies more on bond funding relative to bank lending. To test this hypothesis, we extend our baseline regression by including either i) lagged year-on-year growth of quarterly corporate bond issuance (column 3 in Tables 6-8) or ii) a four-quarter moving average of the ratio of outstanding corporate bonds to outstanding corporate bank credit (column 4 in Tables 6 8), and their interactions with the macroprudential policy variables.

For all measures of riskiness, the result that an unexpected tightening of household-specific macroprudential measures increases corporate credit riskiness is robust to including the growth of corporate bond issuance. The interaction terms of $\bar{\varepsilon}^{H H}$ with corporate bond issuance, while negative in line with our hypothesis, are not statistically significant. At the same time, the interaction terms of $\bar{\varepsilon}^{B C}$ with credit to GDP growth are now statistically significant and negative, while the interaction terms of $\bar{\varepsilon}^{B C}$ with corporate bond issuance are significant and positive. Thus, the impact of tightening of corporate and broad-based MaPP measures on reducing corporate credit riskiness is declining with the volume of recent corporate bond issuance. 
Table (6) Robustness: TDTA measure of credit riskiness

\begin{tabular}{|c|c|c|c|c|c|c|}
\hline VARIABLES & $\begin{array}{c}(1) \\
\text { TDTA }\end{array}$ & $\begin{array}{c}(2) \\
\text { TDTA }\end{array}$ & $\begin{array}{c}(3) \\
\text { TDTA }\end{array}$ & $\begin{array}{c}(4) \\
\text { TDTA }\end{array}$ & $\begin{array}{c}(5) \\
\text { TDTA }\end{array}$ & $\begin{array}{c}(6) \\
\text { TDTA }\end{array}$ \\
\hline$T D T A_{t-1}$ & $\begin{array}{c}0.49^{* * *} \\
(0.04)\end{array}$ & $\begin{array}{c}0.50 * * * \\
(0.05)\end{array}$ & $\begin{array}{c}0.47^{* * *} \\
(0.05)\end{array}$ & $\begin{array}{c}0.47^{* * *} \\
(0.05)\end{array}$ & $\begin{array}{c}0.52^{* * *} \\
(0.02)\end{array}$ & $\begin{array}{c}0.48^{* * *} \\
(0.04)\end{array}$ \\
\hline $\bar{\varepsilon}_{t-1}^{H H}$ & $\begin{array}{c}0.02 \\
(0.03)\end{array}$ & $\begin{array}{c}0.02 \\
(0.03)\end{array}$ & $\begin{array}{c}0.03 \\
(0.03)\end{array}$ & $\begin{array}{c}0.04 \\
(0.08)\end{array}$ & $\begin{array}{l}-0.02 \\
(0.05)\end{array}$ & $\begin{array}{c}0.02 \\
(0.03)\end{array}$ \\
\hline $\bar{\varepsilon}_{t-1}^{B C}$ & $\begin{array}{c}0.02 \\
(0.05)\end{array}$ & $\begin{array}{l}-0.01 \\
(0.04)\end{array}$ & $\begin{array}{c}0.00 \\
(0.05)\end{array}$ & $\begin{array}{l}-0.04 \\
(0.10)\end{array}$ & $\begin{array}{c}0.01 \\
(0.04)\end{array}$ & $\begin{array}{c}0.03 \\
(0.05)\end{array}$ \\
\hline $\bar{\varepsilon}_{t-1}^{H H} \times \Delta$ Credit $_{t-1}$ & $\begin{array}{l}0.01^{*} \\
(0.01)\end{array}$ & $\begin{array}{l}0.01^{*} \\
(0.01)\end{array}$ & $\begin{array}{l}0.01 * * \\
(0.01)\end{array}$ & $\begin{array}{c}0.01 \\
(0.01)\end{array}$ & $\begin{array}{c}0.02^{* * *} \\
(0.01)\end{array}$ & $\begin{array}{l}0.01^{*} \\
(0.01)\end{array}$ \\
\hline $\bar{\varepsilon}_{t-1}^{B C} \times \Delta$ Credit $_{t-1}$ & $\begin{array}{l}-0.02^{*} \\
(0.01)\end{array}$ & $\begin{array}{l}-0.02 \\
(0.01)\end{array}$ & $\begin{array}{c}-0.03^{* *} \\
(0.01)\end{array}$ & $\begin{array}{l}-0.02 \\
(0.01)\end{array}$ & $\begin{array}{l}-0.02^{*} \\
(0.01)\end{array}$ & $\begin{array}{l}-0.02^{*} \\
(0.01)\end{array}$ \\
\hline$\Delta$ Credit $_{t-1}$ & $\begin{array}{l}0.01 * * \\
(0.01)\end{array}$ & $\begin{array}{c}0.01 \\
(0.01)\end{array}$ & $\begin{array}{c}0.02^{* *} \\
(0.01)\end{array}$ & $\begin{array}{l}0.01^{*} \\
(0.01)\end{array}$ & $\begin{array}{l}0.01^{*} \\
(0.00)\end{array}$ & $\begin{array}{l}0.01^{* *} \\
(0.01)\end{array}$ \\
\hline$\Delta G D P_{t-1}$ & $\begin{array}{l}0.03^{* *} \\
(0.01)\end{array}$ & $\begin{array}{c}0.04^{* * *} \\
(0.01)\end{array}$ & $\begin{array}{c}0.04^{* * *} \\
(0.01)\end{array}$ & $\begin{array}{c}0.04^{* * *} \\
(0.01)\end{array}$ & $\begin{array}{c}0.03^{* *} \\
(0.01)\end{array}$ & $\begin{array}{l}0.03^{* *} \\
(0.01)\end{array}$ \\
\hline$\Delta_{q} E R_{t-1}$ & $\begin{array}{c}-0.02^{* *} \\
(0.01)\end{array}$ & $\begin{array}{c}-0.02^{* *} \\
(0.01)\end{array}$ & $\begin{array}{c}-0.02^{* *} \\
(0.01)\end{array}$ & $\begin{array}{c}-0.02^{* * *} \\
(0.01)\end{array}$ & $\begin{array}{c}-0.02^{* *} \\
(0.01)\end{array}$ & $\begin{array}{c}-0.02^{* * *} \\
(0.01)\end{array}$ \\
\hline$F C I_{t-1}$ & $\begin{array}{c}-0.13^{* *} \\
(0.05)\end{array}$ & $\begin{array}{c}-0.15^{* * *} \\
(0.04)\end{array}$ & $\begin{array}{l}-0.07 \\
(0.05)\end{array}$ & $\begin{array}{l}-0.07 \\
(0.05)\end{array}$ & $\begin{array}{c}-0.14^{* *} \\
(0.06)\end{array}$ & $\begin{array}{l}-0.12^{*} \\
(0.06)\end{array}$ \\
\hline Global Volatility & & $\begin{array}{c}0.10^{* * *} \\
(0.03)\end{array}$ & & & & \\
\hline Fed Funds Rate (Difference) & & $\begin{array}{l}-0.00 \\
(0.04)\end{array}$ & & & & \\
\hline$\Delta N F C B$ Bond $s_{t-1}$ & & & $\begin{array}{l}-0.03 \\
(0.05)\end{array}$ & & & \\
\hline $\bar{\varepsilon}_{t-1}^{H H} \times \Delta N F C$ Bond $s_{t-1}$ & & & $\begin{array}{l}-0.16 \\
(0.09)\end{array}$ & & & \\
\hline $\bar{\varepsilon}_{t-1}^{B C} \times \Delta N F C$ Bonds $s_{t-1}$ & & & $\begin{array}{c}0.53 \\
(0.37)\end{array}$ & & & \\
\hline Bond_credit_ratio_ma & & & & $\begin{array}{l}-0.01 \\
(0.00)\end{array}$ & & \\
\hline $\bar{\varepsilon}_{t-1}^{H H} \times$ Bond_credit_ratio_ma & & & & $\begin{array}{l}-0.00 \\
(0.00)\end{array}$ & & \\
\hline $\bar{\varepsilon}_{t-1}^{B C} \times$ Bond_credit_ratio_ma & & & & $\begin{array}{c}0.01 \\
(0.01)\end{array}$ & & \\
\hline$\Delta H P I_{t-1}$ & & & & & & $\begin{array}{c}0.00 \\
(0.00)\end{array}$ \\
\hline Observations & 1,108 & 1,108 & 1,026 & 1,013 & 924 & 1,108 \\
\hline Number of Countries & 21 & 21 & 21 & 20 & 18 & 21 \\
\hline Adjusted R-squared & 0.40 & 0.37 & 0.39 & 0.39 & 0.42 & 0.40 \\
\hline Country FE & Yes & Yes & Yes & Yes & Yes & Yes \\
\hline Time FE & Yes & No & Yes & Yes & Yes & Yes \\
\hline
\end{tabular}

Robust standard errors in parentheses

$* * * \mathrm{p}<0.01, * * \mathrm{p}<0.05, * \mathrm{p}<0.1$

Note: Additional variables - "Global Volatility" stands for MSCI World Index, "Fed funds rate (Difference)" is the quarterly change in FFR/ Wu-Xia shadow rate, FCI is the domestic financial conditions index, $\triangle N F C B$ onds is yoy growth in outstanding bonds to the nonfinancial corporate sector relative to GDP, "Bond_credit_ratio_ma" is a 4-quarter moving average of the ratio of outstanding NFC bonds to outstanding NFC bank loans, $\triangle H P I$ is yoy real house price growth. 
Table (7) Robustness: TDtE measure of credit riskiness

\begin{tabular}{|c|c|c|c|c|c|c|}
\hline VARIABLES & $\begin{array}{c}(1) \\
\text { TDtE }\end{array}$ & $\begin{array}{c}(2) \\
\text { TDtE }\end{array}$ & $\begin{array}{c}(3) \\
\text { TDtE }\end{array}$ & $\begin{array}{c}(4) \\
\text { TDtE }\end{array}$ & $\begin{array}{c}(5) \\
\text { TDtE }\end{array}$ & $\begin{array}{c}(6) \\
\text { TDtE }\end{array}$ \\
\hline$T D t E_{t-1}$ & $\begin{array}{c}0.36^{* * *} \\
(0.03)\end{array}$ & $\begin{array}{c}0.37^{* * *} \\
(0.04)\end{array}$ & $\begin{array}{c}0.36^{* * *} \\
(0.04)\end{array}$ & $\begin{array}{c}0.35^{* * *} \\
(0.04)\end{array}$ & $\begin{array}{c}0.37^{* * *} \\
(0.03)\end{array}$ & $\begin{array}{c}0.36^{* * *} \\
(0.03)\end{array}$ \\
\hline $\bar{\varepsilon}_{t-1}^{H H}$ & $\begin{array}{c}-0.09^{* *} \\
(0.04)\end{array}$ & $\begin{array}{l}-0.07^{*} \\
(0.04)\end{array}$ & $\begin{array}{c}-0.09^{* *} \\
(0.04)\end{array}$ & $\begin{array}{c}0.00 \\
(0.08)\end{array}$ & $\begin{array}{l}-0.05 \\
(0.06)\end{array}$ & $\begin{array}{c}-0.09^{* *} \\
(0.04)\end{array}$ \\
\hline $\bar{\varepsilon}_{t-1}^{B C}$ & $\begin{array}{c}0.02 \\
(0.08)\end{array}$ & $\begin{array}{c}0.05 \\
(0.09)\end{array}$ & $\begin{array}{l}-0.03 \\
(0.10)\end{array}$ & $\begin{array}{l}-0.05 \\
(0.10)\end{array}$ & $\begin{array}{c}0.01 \\
(0.08)\end{array}$ & $\begin{array}{c}0.02 \\
(0.08)\end{array}$ \\
\hline $\bar{\varepsilon}_{t-1}^{H H} \times \Delta$ Credit $_{t-1}$ & $\begin{array}{c}0.02^{* * *} \\
(0.01)\end{array}$ & $\begin{array}{l}0.02^{* *} \\
(0.01)\end{array}$ & $\begin{array}{c}0.02^{* * *} \\
(0.01)\end{array}$ & $\begin{array}{l}0.02^{* *} \\
(0.01)\end{array}$ & $\begin{array}{l}0.02^{* *} \\
(0.01)\end{array}$ & $\begin{array}{c}0.02^{* * *} \\
(0.01)\end{array}$ \\
\hline $\bar{\varepsilon}_{t-1}^{B C} \times \Delta$ Credit $_{t-1}$ & $\begin{array}{l}-0.01 \\
(0.01)\end{array}$ & $\begin{array}{l}-0.02 \\
(0.01)\end{array}$ & $\begin{array}{c}-0.04^{* *} \\
(0.02)\end{array}$ & $\begin{array}{l}-0.01 \\
(0.01)\end{array}$ & $\begin{array}{l}-0.01 \\
(0.01)\end{array}$ & $\begin{array}{l}-0.01 \\
(0.01)\end{array}$ \\
\hline$\Delta$ Credit $_{t-1}$ & $\begin{array}{c}0.02^{* *} \\
(0.01)\end{array}$ & $\begin{array}{c}0.02^{* * *} \\
(0.01)\end{array}$ & $\begin{array}{c}0.02^{* *} \\
(0.01)\end{array}$ & $\begin{array}{l}0.02^{*} \\
(0.01)\end{array}$ & $\begin{array}{l}0.02^{* *} \\
(0.01)\end{array}$ & $\begin{array}{c}0.02^{* *} \\
(0.01)\end{array}$ \\
\hline$\Delta G D P_{t-1}$ & $\begin{array}{l}0.05^{* *} \\
(0.02)\end{array}$ & $\begin{array}{c}0.04^{* * *} \\
(0.02)\end{array}$ & $\begin{array}{c}0.05^{* * *} \\
(0.02)\end{array}$ & $\begin{array}{l}0.05^{* *} \\
(0.02)\end{array}$ & $\begin{array}{l}0.04^{* *} \\
(0.02)\end{array}$ & $\begin{array}{c}0.05^{* * *} \\
(0.02)\end{array}$ \\
\hline$\Delta_{q} E R_{t-1}$ & $\begin{array}{c}0.00 \\
(0.01)\end{array}$ & $\begin{array}{c}0.01 \\
(0.01)\end{array}$ & $\begin{array}{c}0.00 \\
(0.01)\end{array}$ & $\begin{array}{l}-0.00 \\
(0.01)\end{array}$ & $\begin{array}{c}0.00 \\
(0.01)\end{array}$ & $\begin{array}{l}0.00 \\
(0.01)\end{array}$ \\
\hline$F C I_{t-1}$ & $\begin{array}{c}-0.21^{* *} \\
(0.08)\end{array}$ & $\begin{array}{c}-0.17^{* *} \\
(0.07)\end{array}$ & $\begin{array}{l}-0.16^{*} \\
(0.09)\end{array}$ & $\begin{array}{l}-0.16 \\
(0.10)\end{array}$ & $\begin{array}{c}-0.22^{* *} \\
(0.09)\end{array}$ & $\begin{array}{c}-0.21^{* *} \\
(0.09)\end{array}$ \\
\hline Global Volatility & & $\begin{array}{l}0.07^{*} \\
(0.03)\end{array}$ & & & & \\
\hline Fed Funds Rate (Difference) & & $\begin{array}{l}-0.02 \\
(0.06)\end{array}$ & & & & \\
\hline$\Delta N F C$ Bond $_{t-1}$ & & & $\begin{array}{c}0.00 \\
(0.03)\end{array}$ & & & \\
\hline $\bar{\varepsilon}_{t-1}^{H H} \times \Delta N F C B$ Bond $s_{t-1}$ & & & $\begin{array}{l}-0.08 \\
(0.08)\end{array}$ & & & \\
\hline $\bar{\varepsilon}_{t-1}^{B C} \times \Delta N F C$ Bond $s_{t-1}$ & & & $\begin{array}{l}1.15^{* *} \\
(0.55)\end{array}$ & & & \\
\hline Bond_credit_ratio_ma & & & & $\begin{array}{l}-0.01 \\
(0.01)\end{array}$ & & \\
\hline $\bar{\varepsilon}_{t-1}^{H H} \times$ Bond_credit_ratio_ma & & & & $\begin{array}{l}-0.00 \\
(0.00)\end{array}$ & & \\
\hline $\bar{\varepsilon}_{t-1}^{B C} \times$ Bond_credit_ratio_ma & & & & $\begin{array}{c}0.01 \\
(0.01)\end{array}$ & & \\
\hline$\Delta H P I_{t-1}$ & & & & & & $\begin{array}{c}0.00 \\
(0.01)\end{array}$ \\
\hline Observations & 1,098 & 1,098 & 1,017 & 1,003 & 921 & 1,098 \\
\hline Number of Countries & 21 & 21 & 21 & 20 & 18 & 21 \\
\hline Adjusted R-squared & 0.26 & 0.26 & 0.26 & 0.26 & 0.28 & 0.26 \\
\hline Country FE & Yes & Yes & Yes & Yes & Yes & Yes \\
\hline Time FE & Yes & No & Yes & Yes & Yes & Yes \\
\hline
\end{tabular}

Robust standard errors in parentheses $* * * \mathrm{p}<0.01, * * \mathrm{p}<0.05, * \mathrm{p}<0.1$

Note: Additional variables - "Global Volatility" stands for MSCI World Index, "Fed funds rate (Difference)" is the quarterly change in FFR/ Wu-Xia shadow rate, FCI is the domestic financial conditions index, $\triangle N F C B$ onds is yoy growth in outstanding bonds to the nonfinancial corporate sector relative to GDP, "Bond_credit_ratio_ma" is a 4-quarter moving average of the ratio of outstanding NFC bonds to outstanding NFC bank loans, $\triangle H P I$ is yoy real house price growth. 
Table (8) Robustness: ICR measure of credit riskiness

\begin{tabular}{|c|c|c|c|c|c|c|}
\hline VARIABLES & $\begin{array}{c}(1) \\
\text { ICR }\end{array}$ & $\begin{array}{c}(2) \\
\mathrm{ICR}\end{array}$ & $\begin{array}{c}(3) \\
\text { ICR }\end{array}$ & $\begin{array}{c}(4) \\
\text { ICR }\end{array}$ & $\begin{array}{c}(5) \\
\text { ICR }\end{array}$ & $\begin{array}{c}(6) \\
\text { ICR }\end{array}$ \\
\hline$I C R_{t-1}$ & $\begin{array}{c}0.32^{* * *} \\
(0.04)\end{array}$ & $\begin{array}{c}0.33^{* * *} \\
(0.04)\end{array}$ & $\begin{array}{c}0.31^{* * *} \\
(0.05)\end{array}$ & $\begin{array}{c}0.30 * * * \\
(0.04)\end{array}$ & $\begin{array}{c}0.33^{* * *} \\
(0.04)\end{array}$ & $\begin{array}{c}0.32^{* * *} \\
(0.04)\end{array}$ \\
\hline $\bar{\varepsilon}_{t-1}^{H H}$ & $\begin{array}{l}-0.05 \\
(0.04)\end{array}$ & $\begin{array}{l}-0.03 \\
(0.03)\end{array}$ & $\begin{array}{l}-0.05 \\
(0.04)\end{array}$ & $\begin{array}{c}0.06 \\
(0.09)\end{array}$ & $\begin{array}{l}-0.04 \\
(0.07)\end{array}$ & $\begin{array}{l}-0.05 \\
(0.04)\end{array}$ \\
\hline $\bar{\varepsilon}_{t-1}^{B C}$ & $\begin{array}{c}0.01 \\
(0.07)\end{array}$ & $\begin{array}{c}0.03 \\
(0.06)\end{array}$ & $\begin{array}{l}-0.02 \\
(0.08)\end{array}$ & $\begin{array}{l}-0.10 \\
(0.09)\end{array}$ & $\begin{array}{c}0.01 \\
(0.07)\end{array}$ & $\begin{array}{c}0.01 \\
(0.07)\end{array}$ \\
\hline $\bar{\varepsilon}_{t-1}^{H H} \times \Delta$ Credit $_{t-1}$ & $\begin{array}{l}0.02^{*} \\
(0.01)\end{array}$ & $\begin{array}{l}0.01^{*} \\
(0.01)\end{array}$ & $\begin{array}{l}0.02^{*} \\
(0.01)\end{array}$ & $\begin{array}{c}0.01 \\
(0.01)\end{array}$ & $\begin{array}{l}0.02^{*} \\
(0.01)\end{array}$ & $\begin{array}{l}0.02^{*} \\
(0.01)\end{array}$ \\
\hline $\bar{\varepsilon}_{t-1}^{B C} \times \Delta$ Credit $_{t-1}$ & $\begin{array}{l}-0.02 \\
(0.02)\end{array}$ & $\begin{array}{l}-0.03 \\
(0.02)\end{array}$ & $\begin{array}{c}-0.04^{* *} \\
(0.02)\end{array}$ & $\begin{array}{l}-0.02 \\
(0.02)\end{array}$ & $\begin{array}{l}-0.02 \\
(0.02)\end{array}$ & $\begin{array}{l}-0.02 \\
(0.02)\end{array}$ \\
\hline$\Delta$ Credit $_{t-1}$ & $\begin{array}{c}0.01 \\
(0.01)\end{array}$ & $\begin{array}{l}0.02^{*} \\
(0.01)\end{array}$ & $\begin{array}{c}0.01 \\
(0.01)\end{array}$ & $\begin{array}{c}0.01 \\
(0.01)\end{array}$ & $\begin{array}{c}0.01 \\
(0.01)\end{array}$ & $\begin{array}{l}0.01^{*} \\
(0.01)\end{array}$ \\
\hline$\Delta G D P_{t-1}$ & $\begin{array}{c}0.02 \\
(0.02)\end{array}$ & $\begin{array}{c}0.02 \\
(0.02)\end{array}$ & $\begin{array}{c}0.03 \\
(0.02)\end{array}$ & $\begin{array}{c}0.02 \\
(0.02)\end{array}$ & $\begin{array}{c}0.01 \\
(0.02)\end{array}$ & $\begin{array}{c}0.02 \\
(0.01)\end{array}$ \\
\hline$\Delta_{q} E R_{t-1}$ & $\begin{array}{c}0.00 \\
(0.01)\end{array}$ & $\begin{array}{c}0.01 \\
(0.01)\end{array}$ & $\begin{array}{c}0.00 \\
(0.01)\end{array}$ & $\begin{array}{c}0.00 \\
(0.01)\end{array}$ & $\begin{array}{c}0.01 \\
(0.01)\end{array}$ & $\begin{array}{c}0.00 \\
(0.01)\end{array}$ \\
\hline$F C I_{t-1}$ & $\begin{array}{c}-0.20^{* *} \\
(0.08)\end{array}$ & $\begin{array}{c}-0.17^{* *} \\
(0.06)\end{array}$ & $\begin{array}{c}-0.15^{*} \\
(0.08)\end{array}$ & $\begin{array}{l}-0.15^{*} \\
(0.09)\end{array}$ & $\begin{array}{c}-0.21^{* *} \\
(0.09)\end{array}$ & $\begin{array}{c}-0.21^{* *} \\
(0.09)\end{array}$ \\
\hline Global Volatility & & $\begin{array}{c}0.11^{* * *} \\
(0.04)\end{array}$ & & & & \\
\hline Fed Funds Rate (Difference) & & $\begin{array}{l}-0.04 \\
(0.06)\end{array}$ & & & & \\
\hline$\Delta N F C$ Bond $s_{t-1}$ & & & $\begin{array}{c}0.00 \\
(0.03)\end{array}$ & & & \\
\hline $\bar{\varepsilon}_{t-1}^{H H} \times \Delta N F C B$ Bond $s_{t-1}$ & & & $\begin{array}{l}-0.11 \\
(0.11)\end{array}$ & & & \\
\hline $\bar{\varepsilon}_{t-1}^{B C} \times \Delta N F C$ Bonds $s_{t-1}$ & & & $\begin{array}{l}0.99^{*} \\
(0.48)\end{array}$ & & & \\
\hline Bond_credit_ratio_ma & & & & $\begin{array}{l}-0.01 \\
(0.00)\end{array}$ & & \\
\hline $\bar{\varepsilon}_{t-1}^{H H} \times$ Bond_credit_ratio_ma & & & & $\begin{array}{l}-0.00 \\
(0.00)\end{array}$ & & \\
\hline $\bar{\varepsilon}_{t-1}^{B C} \times$ Bond_credit_ratio_ma & & & & $\begin{array}{c}0.01 \\
(0.01)\end{array}$ & & \\
\hline$\Delta H P I_{t-1}$ & & & & & & $\begin{array}{l}-0.00 \\
(0.01)\end{array}$ \\
\hline Observations & 1,108 & 1,108 & 1,026 & 1,013 & 924 & 1,108 \\
\hline Number of Countries & 21 & 21 & 21 & 20 & 18 & 21 \\
\hline Adjusted R-squared & 0.19 & 0.20 & 0.19 & 0.19 & 0.20 & 0.19 \\
\hline Country FE & Yes & Yes & Yes & Yes & Yes & Yes \\
\hline Time FE & Yes & No & Yes & Yes & Yes & Yes \\
\hline
\end{tabular}

Robust standard errors in parentheses $* * * \mathrm{p}<0.01, * * \mathrm{p}<0.05, * \mathrm{p}<0.1$

Note: Additional variables - "Global Volatility" stands for MSCI World Index, "Fed funds rate (Difference)" is the quarterly change in FFR/ Wu-Xia shadow rate, FCI is the domestic financial conditions index, $\triangle N F C B$ onds is yoy growth in outstanding bonds to the nonfinancial corporate sector relative to GDP, "Bond_credit_ratio_ma" is a 4-quarter moving average of the ratio of outstanding NFC bonds to outstanding NFC bank loans, $\triangle H P I$ is yoy real house price growth. 
When including the ratio of corporate bonds to corporate bank credit, the interaction term between the $\bar{\varepsilon}^{H H}$ and credit to GDP growth, while positive across the three measures of corporate credit riskiness, is only significant for the TDtE measure. At the same time, the interaction of $\bar{\varepsilon}^{H H}$ with the bonds-to-bank credit ratio, while again negative, is never statistically significant.

We also check whether our results are not due to individual countries. In column 5 in Tables 66 we exclude three countries (Canada, Netherlands, and South Korea) that predominantly used household-specific MaPPs and had very few or no instances of the corporate-specific or broad-based macroprudential policy changes. The results are robust to exclusion of the outliers.

It is also possible that our results are driven purely by the positive correlation between the corporate credit riskiness and the situation in the domestic household credit markets. In this case, a tightening in household-specific MaPPs in response to vulnerabilities building up for example in the housing market (as reflected e.g. in the rapid house price growth) could spuriously show up as amplifying risks in the corporate sector as well. To exclude that possibility, besides using macroprudential policy shocks, in column 6 of Tables 6,8 we also control for a lag of year-on-year growth in real house prices. The results remain statistically significant. As an additional test, we compute the correlation between year-on-year real house price growth and the three measures of corporate credit riskiness. The cross-country average of that correlation is low, and ranges between 0.08 and 0.14 for the three measures. Yet, since there is considerable variation between countries, we rerun regressions when excluding five countries for which the correlation between house price growth and corporate riskiness exceeded 0.4 on average (Brazil, Finland, Italy, Poland and Spain). The results (not shown) remain unchanged.

Additional robustness exercises. In Appendices A.4 and A.5 we show that the results carry through when using local projections akin to Jordá (2005), and when using macroprudential policy actions instead of policy shocks. We also check that the results are robust to using Discroll-Kraay standard errors to control for potential cross-section correlation of standard errors. However, since this way of computing standard errors involves imposing restrictions on the autocorrelation process, and because autocorrelation seems to be of more concern in our dynamic specification than cross-section correlation, we use robust standard errors throughout the paper. ${ }^{17}$ We also verify that all the results hold when using the pooled mean group estimator of Pesaran, Shin, and Smith $(1997,1999)$ that allows for heterogeneity in error variances across countries.

Alternative definitions of MaPP measures. To further validate our results, we replace our MaPP shocks with shocks constructed using the alternate indicators of $M a P P^{H H}$ and $M a P P^{B C}$, as explained in Section 3 . Table 9 show the results.

\footnotetext{
${ }^{17}$ In all regressions we include time fixed effects, which should mitigate the cross-section correlation concerns.
} 
Table (9) Alternative definitions of MaPP measures

\begin{tabular}{|c|c|c|c|c|c|c|}
\hline VARIABLES & $\begin{array}{c}(1) \\
\text { TDTA }\end{array}$ & $\begin{array}{c}(2) \\
\text { ICR }\end{array}$ & $\begin{array}{c}(3) \\
\text { TDtE }\end{array}$ & $\begin{array}{c}(4) \\
\text { TDTA }\end{array}$ & $\begin{array}{c}(5) \\
\text { ICR }\end{array}$ & $\begin{array}{c}(6) \\
\text { TDtE }\end{array}$ \\
\hline DependentVariable $_{t-1}$ & $\begin{array}{c}0.489^{* * *} \\
(0.043)\end{array}$ & $\begin{array}{c}0.326^{* * *} \\
(0.040)\end{array}$ & $\begin{array}{c}0.381^{* * *} \\
(0.037)\end{array}$ & $\begin{array}{c}0.485^{* * *} \\
(0.042)\end{array}$ & $\begin{array}{c}0.326^{* * *} \\
(0.040)\end{array}$ & $\begin{array}{c}0.381^{* * *} \\
(0.037)\end{array}$ \\
\hline $\bar{\varepsilon}_{t-1}^{H H, \text { Alternate }}$ & $\begin{array}{c}0.023 \\
(0.025)\end{array}$ & $\begin{array}{l}-0.019 \\
(0.029)\end{array}$ & $\begin{array}{l}-0.047 \\
(0.039)\end{array}$ & & & \\
\hline $\bar{\varepsilon}_{t-1}^{H H, \text { Alternate }} \times \Delta$ Credit $_{t-1}$ & $\begin{array}{c}0.008 \\
(0.006)\end{array}$ & $\begin{array}{l}0.009^{*} \\
(0.005)\end{array}$ & $\begin{array}{c}0.014^{* *} \\
(0.005)\end{array}$ & & & \\
\hline $\bar{\varepsilon}_{t-1}^{B C}$ & $\begin{array}{c}0.021 \\
(0.043)\end{array}$ & $\begin{array}{c}0.021 \\
(0.065)\end{array}$ & $\begin{array}{c}0.030 \\
(0.077)\end{array}$ & & & \\
\hline $\bar{\varepsilon}_{t-1}^{B C} \times \Delta$ Credit $t_{t-1}$ & $\begin{array}{l}-0.018 \\
(0.012)\end{array}$ & $\begin{array}{l}-0.022 \\
(0.019)\end{array}$ & $\begin{array}{l}-0.014 \\
(0.014)\end{array}$ & & & \\
\hline$\Delta$ Credit $_{t-1}$ & $\begin{array}{c}0.018^{* * *} \\
(0.006)\end{array}$ & $\begin{array}{c}0.022^{* *} \\
(0.009)\end{array}$ & $\begin{array}{c}0.028^{* * *} \\
(0.008)\end{array}$ & $\begin{array}{c}0.020^{* * *} \\
(0.005)\end{array}$ & $\begin{array}{c}0.023^{* *} \\
(0.009)\end{array}$ & $\begin{array}{c}0.029^{* * *} \\
(0.008)\end{array}$ \\
\hline$\Delta G D P_{t-1}$ & $\begin{array}{c}0.040^{* * *} \\
(0.011)\end{array}$ & $\begin{array}{c}0.030^{* *} \\
(0.012)\end{array}$ & $\begin{array}{c}0.054^{* * *} \\
(0.015)\end{array}$ & $\begin{array}{c}0.043^{* * *} \\
(0.010)\end{array}$ & $\begin{array}{c}0.034^{* * *} \\
(0.012)\end{array}$ & $\begin{array}{c}0.056^{* * *} \\
(0.015)\end{array}$ \\
\hline$\Delta_{q} E R_{t-1}$ & $\begin{array}{c}-0.010^{*} \\
(0.005)\end{array}$ & $\begin{array}{c}0.013^{* *} \\
(0.006)\end{array}$ & $\begin{array}{c}0.010 \\
(0.006)\end{array}$ & $\begin{array}{c}-0.011^{*} \\
(0.005)\end{array}$ & $\begin{array}{l}0.012^{*} \\
(0.006)\end{array}$ & $\begin{array}{c}0.009 \\
(0.006)\end{array}$ \\
\hline $\bar{\varepsilon}_{t-1}^{H H}$ & & & & $\begin{array}{c}0.018 \\
(0.025)\end{array}$ & $\begin{array}{l}-0.031 \\
(0.031)\end{array}$ & $\begin{array}{c}-0.070^{*} \\
(0.038)\end{array}$ \\
\hline $\bar{\varepsilon}_{t-1}^{H H} \times \Delta$ Credit $_{t-1}$ & & & & $\begin{array}{c}0.013^{* *} \\
(0.005)\end{array}$ & $\begin{array}{l}0.013^{*} \\
(0.007)\end{array}$ & $\begin{array}{c}0.022^{* *} \\
(0.009)\end{array}$ \\
\hline $\bar{\varepsilon}_{t-1}^{B C, \text { Alternate }}$ & & & & $\begin{array}{c}0.014 \\
(0.107)\end{array}$ & $\begin{array}{c}0.024 \\
(0.082)\end{array}$ & $\begin{array}{c}0.040 \\
(0.111)\end{array}$ \\
\hline $\bar{\varepsilon}_{t-1}^{B C, \text { Alternate }} \times \Delta$ Credit $_{t-1}$ & & & & $\begin{array}{l}-0.025 \\
(0.015)\end{array}$ & $\begin{array}{l}-0.015 \\
(0.025)\end{array}$ & $\begin{array}{l}-0.022 \\
(0.026)\end{array}$ \\
\hline Observations & 1,257 & 1,257 & 1,247 & 1,257 & 1,257 & 1,247 \\
\hline Number of Countries & 24 & 24 & 24 & 24 & 24 & 24 \\
\hline Adjusted R-squared & 0.380 & 0.172 & 0.253 & 0.380 & 0.171 & 0.254 \\
\hline Country FE & Yes & Yes & Yes & Yes & Yes & Yes \\
\hline Time FE & Yes & Yes & Yes & Yes & Yes & Yes \\
\hline Alternate HH measure & Yes & Yes & Yes & & & \\
\hline Alternate $\mathrm{BC}$ measure & & & & Yes & Yes & Yes \\
\hline
\end{tabular}

Note: $\bar{\varepsilon}_{t-1}^{H H(B C), \text { Alternate }}$ is the lagged sum of alternative measure of $M a P P^{H H(B C)}$ shock in past four quarters, $\bar{\varepsilon}_{t-1}^{H H(B C)}$ is the lagged sum of the baseline $M a P P^{H H(B C)}$ shocks in past four quarter, $\Delta C r e d i t_{t-1}$ is the lagged yoy growth of credit to non-financial private sector relative to GDP, $\triangle G D P_{t-1}$ is the lagged yoy Real GDP growth, $\Delta_{q} E R_{t-1}$ is the lagged qoq local currency appreciation rate against USD.

Columns 1-3 consider a specification where the household-specific MaPP shocks are con- 
structed using the alternate $M a P P^{H H}$ indicator. We see that the interaction term of $\bar{\varepsilon}^{H H, \text { Alternate }}$ with the credit to GDP growth is always positive although ceases to be statistically significant for the TDTA riskiness measure 18

Similarly, columns 4-6 in Table 9 show the results when using the alternate definition of $M a P P^{B C}$ to construct broad-based and corporate sector-specific MaPP shocks. The interaction term of the baseline household-specific MaPP shock with credit to GDP growth is always positive and statistically significant for all three measures of corporate credit riskiness.

\subsection{Lending standards from loan officer surveys}

As a final robustness exercise, and to extend our analysis, we collect data on changes in the lending standards for corporate loans as reported by bank loan officers in surveys. This allows us to focus on bank credit availability more explicitly as compared to the corporate credit riskiness indicators constructed in Section $33^{19}$ As the loan officer surveys provide information on loan lending standards by the firm size, we can study the impact of MaPP actions on bank loans to SMEs and large corporates separately. Columns 1, 3 and 5 in Table 10 show the results from the baseline regression (3) for all corporations, SMEs and to large corporates respectively ${ }^{20}$ Columns 2, 4 and 6 in Table 10 further control for domestic conditions using the local 3-month money market rates ${ }^{21}$ When interpreting the results, it is important to remember that positive values of the lending standards variable mean tightened standards, and negative values - eased lending standards.

Across all specifications, the joint significance tests of the four lags of the household-specific macroprudential shocks show they are statistically significant, but the direction of the impact varies by the firm size. In particular, regressions for lending standards for all corporates and for SMEs show a positive (i.e. tightening) impact of past unexpected MaPP tightenings on the lending standards by banks. However, the opposite is true for large corporates, where the net impact of MaPP tightening shocks in the past four quarters is negative, suggesting an easing of lending conditions by banks.

\footnotetext{
${ }^{18}$ This result suggests that restrictions on loan characteristics might be relatively less binding that other MaPP measures we consider.

${ }^{19}$ While many central banks use loan officer surveys to gauge the extent of tightening or relaxing lending standards, a potential concern might be that respondents could strategically offer responses consistent with outcomes desired by the central banks or bank supervisors rather than actual changes in lending standards.

${ }^{20}$ We also ran the regression (4) but since only the standalone terms of the macroprudential policy shocks were statistically significant, we decided to use the baseline specification without interaction with credit growth.

${ }^{21}$ We use the 3-month market rates instead of domestic FCI to maximize the number of countries in the sample.
} 
Table (10) Bank Lending Standards for Corporate Loans

\begin{tabular}{|c|c|c|c|c|c|c|}
\hline VARIABLES & $\begin{array}{c}(1) \\
\text { LS(All) }\end{array}$ & $\begin{array}{c}(2) \\
\text { LS(All) }\end{array}$ & $\begin{array}{c}(3) \\
\text { LS(SMEs) }\end{array}$ & $\begin{array}{c}(4) \\
\text { LS(SMEs) }\end{array}$ & $\begin{array}{c}(5) \\
\text { LS(Large) }\end{array}$ & $\begin{array}{c}(6) \\
\text { LS(Large) }\end{array}$ \\
\hline DependentVariable $e_{t-1}$ & $\begin{array}{c}0.716^{* * *} \\
(0.068)\end{array}$ & $\begin{array}{c}0.716^{* * *} \\
(0.070)\end{array}$ & $\begin{array}{c}0.680^{* * *} \\
(0.079)\end{array}$ & $\begin{array}{c}0.681^{* * *} \\
(0.082)\end{array}$ & $\begin{array}{c}0.680^{* * *} \\
(0.080)\end{array}$ & $\begin{array}{c}0.675^{* * *} \\
(0.086)\end{array}$ \\
\hline$\varepsilon^{H H}, \operatorname{Lag} 1$ & $\begin{array}{c}1.301^{* *} \\
(0.576)\end{array}$ & $\begin{array}{c}1.302^{* *} \\
(0.591)\end{array}$ & $\begin{array}{l}1.897^{*} \\
(1.034)\end{array}$ & $\begin{array}{l}1.892^{*} \\
(1.045)\end{array}$ & $\begin{array}{c}0.043 \\
(0.743)\end{array}$ & $\begin{array}{c}0.076 \\
(0.745)\end{array}$ \\
\hline$\varepsilon^{H H}, \operatorname{Lag} 2$ & $\begin{array}{l}-1.216 \\
(0.744)\end{array}$ & $\begin{array}{l}-1.216 \\
(0.744)\end{array}$ & $\begin{array}{l}-1.351 \\
(0.880)\end{array}$ & $\begin{array}{l}-1.352 \\
(0.880)\end{array}$ & $\begin{array}{l}-0.991 \\
(0.872)\end{array}$ & $\begin{array}{l}-0.990 \\
(0.876)\end{array}$ \\
\hline$\varepsilon^{H H}$, Lag 3 & $\begin{array}{l}-0.503 \\
(0.737)\end{array}$ & $\begin{array}{l}-0.503 \\
(0.741)\end{array}$ & $\begin{array}{c}0.687 \\
(1.010)\end{array}$ & $\begin{array}{c}0.687 \\
(1.011)\end{array}$ & $\begin{array}{l}-1.616^{*} \\
(0.869)\end{array}$ & $\begin{array}{l}-1.615^{*} \\
(0.863)\end{array}$ \\
\hline$\varepsilon^{H H}$, Lag 4 & $\begin{array}{l}-1.440 \\
(0.916)\end{array}$ & $\begin{array}{l}-1.440 \\
(0.915)\end{array}$ & $\begin{array}{l}-0.037 \\
(0.934)\end{array}$ & $\begin{array}{l}-0.041 \\
(0.929)\end{array}$ & $\begin{array}{l}-0.783 \\
(0.815)\end{array}$ & $\begin{array}{l}-0.774 \\
(0.830)\end{array}$ \\
\hline$\varepsilon^{B C}, \operatorname{Lag} 1$ & $\begin{array}{l}-1.140 \\
(0.900)\end{array}$ & $\begin{array}{l}-1.140 \\
(0.979)\end{array}$ & $\begin{array}{l}-2.258 \\
(1.758)\end{array}$ & $\begin{array}{l}-2.263 \\
(1.770)\end{array}$ & $\begin{array}{l}-2.051^{*} \\
(1.025)\end{array}$ & $\begin{array}{l}-2.010^{*} \\
(1.125)\end{array}$ \\
\hline$\varepsilon^{B C}, \operatorname{Lag} 2$ & $\begin{array}{l}-1.731 \\
(1.348)\end{array}$ & $\begin{array}{l}-1.730 \\
(1.352)\end{array}$ & $\begin{array}{l}-0.036 \\
(1.425)\end{array}$ & $\begin{array}{l}-0.041 \\
(1.430)\end{array}$ & $\begin{array}{l}-2.483 \\
(1.881)\end{array}$ & $\begin{array}{l}-2.448 \\
(1.895)\end{array}$ \\
\hline$\varepsilon^{B C}$, Lag 3 & $\begin{array}{l}-0.680 \\
(1.944)\end{array}$ & $\begin{array}{l}-0.679 \\
(1.805)\end{array}$ & $\begin{array}{c}0.616 \\
(1.261)\end{array}$ & $\begin{array}{c}0.597 \\
(1.220)\end{array}$ & $\begin{array}{c}0.570 \\
(2.174)\end{array}$ & $\begin{array}{c}0.682 \\
(1.985)\end{array}$ \\
\hline$\varepsilon^{B C}, \operatorname{Lag} 4$ & $\begin{array}{l}-1.605 \\
(1.498)\end{array}$ & $\begin{array}{l}-1.604 \\
(1.660)\end{array}$ & $\begin{array}{l}-2.569^{*} \\
(1.297)\end{array}$ & $\begin{array}{l}-2.589^{*} \\
(1.447)\end{array}$ & $\begin{array}{l}-0.382 \\
(1.930)\end{array}$ & $\begin{array}{l}-0.261 \\
(2.087)\end{array}$ \\
\hline$\Delta$ Credit $_{t-1}$ & $\begin{array}{l}0.177^{*} \\
(0.095)\end{array}$ & $\begin{array}{l}0.177^{*} \\
(0.100)\end{array}$ & $\begin{array}{l}0.251^{* *} \\
(0.108)\end{array}$ & $\begin{array}{c}0.254^{* *} \\
(0.112)\end{array}$ & $\begin{array}{c}0.157 \\
(0.128)\end{array}$ & $\begin{array}{c}0.139 \\
(0.137)\end{array}$ \\
\hline$\Delta G D P_{t-1}$ & $\begin{array}{l}0.344^{*} \\
(0.193)\end{array}$ & $\begin{array}{c}0.344^{* *} \\
(0.151)\end{array}$ & $\begin{array}{c}0.310 \\
(0.242)\end{array}$ & $\begin{array}{c}0.302 \\
(0.185)\end{array}$ & $\begin{array}{c}0.365 \\
(0.252)\end{array}$ & $\begin{array}{c}0.414 \\
(0.255)\end{array}$ \\
\hline$\Delta_{q} E R_{t-1}$ & $\begin{array}{c}0.166 \\
(0.132)\end{array}$ & $\begin{array}{c}0.166 \\
(0.117)\end{array}$ & $\begin{array}{c}0.079 \\
(0.148)\end{array}$ & $\begin{array}{c}0.076 \\
(0.132)\end{array}$ & $\begin{array}{c}0.002 \\
(0.123)\end{array}$ & $\begin{array}{c}0.023 \\
(0.115)\end{array}$ \\
\hline$N R_{t-1}$ & & $\begin{array}{c}0.003 \\
(0.539)\end{array}$ & & $\begin{array}{l}-0.053 \\
(0.560)\end{array}$ & & $\begin{array}{c}0.335 \\
(0.583)\end{array}$ \\
\hline Observations & 743 & 743 & 644 & 644 & 644 & 644 \\
\hline Number of Countries & 15 & 15 & 13 & 13 & 13 & 13 \\
\hline Adjusted R-squared & 0.660 & 0.659 & 0.587 & 0.586 & 0.622 & 0.622 \\
\hline Domestic $3-\mathrm{m}$ rate & No & Yes & No & Yes & No & Yes \\
\hline Country FE & Yes & Yes & Yes & Yes & Yes & Yes \\
\hline Time FE & Yes & Yes & Yes & Yes & Yes & Yes \\
\hline p-value (Joint F-test for 4 lags $\varepsilon^{H H}$ ) & 0.06 & 0.06 & 0.08 & 0.08 & 0.03 & 0.03 \\
\hline $\mathrm{p}$-value (Joint $\mathrm{F}$-test for 4 lags $\varepsilon^{B C}$ ) & 0.28 & 0.39 & 0.32 & 0.37 & 0.16 & 0.19 \\
\hline
\end{tabular}

Robust standard errors in parentheses

${ }^{* * *} \mathrm{p}<0.01,{ }^{* *} \mathrm{p}<0.05,{ }^{*} \mathrm{p}<0.1$

Note: Additional variables - NR is the 3-month nominal domestic market interest rate. 
These findings are consistent with the evidence that the owners of small firms oftentimes use personal real estate as collateral for firm loans (Adelino et al. 2016, Bahaj et al. 2019). In particular, Lian and Ma (2020) show, for the U.S., that asset-based (collateralized) loans are more common among small and young firms, compared to large and old corporates who rely more on cash flow-based loans. In the macroprudential policy context, Ayyagari et al. (2018) show varying effects of borrower-based tools on mitigating credit growth by firm size. Finally, the results based on loan officer surveys are also consistent with the results for riskiness of corporate allocation measures, which we constructed using data for listed companies. Overall, the evidence gathered in this paper suggests that the leakages from household-specific MaPPs are likely more pronounced for credit to the large corporates.

\section{A model of bank portfolio choice}

In this Section, we consider a simple model of bank portfolio choice that can account for the main findings of our analysis, i.e. leakages from household-specific MaPPs to corporate lending (both in terms of loan volumes and riskiness of new lending) during the credit booms.

In the model, there is a unit mass of risk-neutral banks that invest in risky projects on behalf of investors. There are two dates: at date 0 the representative bank decides how much to invest in the projects, at date 1 all returns are realized and bank creditors are repaid accordingly.

Investment opportunities. There are two types of projects: A (corporate) and B (retail), each in a unit mass supply. When successful, each project $i$ of type A generates a return $r_{A}>1$ and each project of type $\mathrm{B}$ generates a return $r_{B}>1$. Within each type, the projects differ in terms of the probability of being successful, $p_{k}^{i}$, with $k=\{A, B\}$. The probability of delivering a positive return is such that it declines for each additional project being funded. In particular, denote by $x_{A} \in[0,1]$ the mass of A-type projects funded by the representative bank, and by $x_{B} \in[0,1]$ the mass of B-type projects funded. If we order the projects according to their (declining) success of probability, then the marginal project $\mathrm{A}$ has a probability of success equal $p_{A}^{x_{A}}=1-\theta x_{A}$. For the marginal B-type project this probability is $p_{B}^{x_{B}}=1-\theta x_{B}$, with $\theta \in(0,1)$.

For now we keep $\theta$ fixed. As we will show below, allowing $\theta$ to vary with the risk perceptions among banks and their investors can generate interdependence between investments in portfolios $\mathrm{A}$ and B. Figure 5 plots the success probabilities as a function of the size of the project book. 
Figure (5) Probability of a positive return of project $j \in\{A, B\}$.

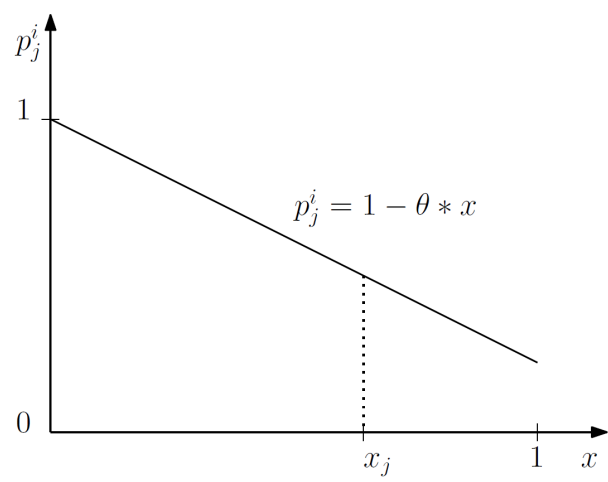

It follows that the expected return on the representative bank's portfolio A of size $x_{A}$ is:

$$
E\left[\pi_{A}\left(x_{A}\right)\right]=\int_{0}^{x_{A}} r_{A}(1-\theta x) d x=r_{A} x_{A}\left(1-\frac{\theta}{2} x_{A}^{2}\right) .
$$

Accordingly, for the bank's portfolio B of size $x_{B}$, the expected return is $E\left[\pi_{B}\left(x_{B}\right)\right]=r_{B} x_{B}(1-$ $\left.\frac{\theta}{2} x_{B}^{2}\right)$.

Funding structure. The representative bank finances its investments, $x_{A}+x_{B}$, through equity $K$ and deposits $D$. Deposits are fully insured and thus yield a rate of return equal to the return on a storage technology, $r_{D}=1$. Equity is costly for the bank, as bank shareholders require a positive rate of return, $r_{K}>12$

Banks are also subject to minimum capital requirements $k_{A} \in(0,1)$ and $k_{B} \in(0,1)$, imposing a minimum share of projects $\mathrm{A}$ and $\mathrm{B}$ to be funded with equity: $K_{A} \geq k_{A} x_{A}$ and $K_{B} \geq k_{B} x_{B}{ }^{23}$ Since $r_{K}>r_{D}$, the bank will always prefer to fund its operations with deposits than with more expensive equity and the capital requirements will always be binding.

The maximum amount of funds-in the form of deposits or equity-available for the banks to finance the projects is limited to $I$ :

$$
x_{A}+x_{B} \leq I .
$$

Bank optimization problem. The representative bank chooses $x_{A}$ and $x_{B}$ to maximize:

$$
\max _{x_{A}, x_{B}} E\left[\pi_{A}\left(x_{A}\right)\right]+E\left[\pi_{B}\left(x_{B}\right)\right]-\left[r_{D}\left(1-k_{A}\right)+r_{K} k_{A}\right] x_{A}-\left[r_{D}\left(1-k_{B}\right)+r_{K} k_{B}\right] x_{B}
$$

subject to (6). The terms $r_{D}\left(1-k_{A}\right)+r_{K} k_{A}$ and $r_{D}\left(1-k_{B}\right)+r_{K} k_{B}$ stand for the unit funding costs for projects $\mathrm{A}$ and $\mathrm{B}$, respectively, where we use that the capital requirements are

\footnotetext{
${ }^{22}$ In this simple way we capture the well-documented preference of financial intermediaries for debt funding. Note that while we do not have aggregate uncertainty in the model, a positive $r_{K}$ could emerge in the presence of aggregate risk even if bank shareholders are risk-neutral.

${ }^{23}$ While we do not microfound the reasons for the introduction of capital requirements, one can think of regulations emerging as an attempt of the regulators to limit the costs of providing deposit insurance when bank managers are protected by limited liability.
} 
always binding. The solution to the optimization problem (7) depends on whether the resource constraint (6) binds or not.

Case I: $x_{A}+x_{B}<I$. It is straightforward to show that when the bank is not constrained by the supply of funding, investments in the two portfolios $\mathrm{A}$ and $\mathrm{B}$ are independent of each other and equal to:

$$
x_{A}^{*}=\frac{r_{A}-1-k_{A}\left(r_{K}-1\right)}{\theta r_{A}},
$$

and

$$
x_{B}^{*}=\frac{r_{B}-1-k_{B}\left(r_{K}-1\right)}{\theta r_{B}} .
$$

The size of each portfolio increases with the expected return, declines with the level of the capital requirement and with the return on equity. At the same time, the probability of success of a marginal project in each of the two portfolios, $1-x_{j}$ with $j \in\{A, B\}$, and the average probability of success of a project in a portfolio both decline in the size of the investment.

Case II: $x_{A}+x_{B}=I$. When the bank hits the limit $I$ of funds available from investors, a simple substitution of $x_{B}=I-x_{A}$ yields the following solution:

$$
x_{A}^{*}=\frac{r_{A}-r_{B}+r_{B} I-\left(k_{A}-k_{B}\right)\left(r_{K}-1\right)}{\theta\left(r_{A}+r_{B}\right)},
$$

and

$$
x_{B}^{*}=I-x_{A}^{*} .
$$

A higher investment in A-type projects reduces investment in B-type projects and vice-versa. Additionally, a higher capital requirement on B-type (retail) projects increases bank's investment in projects A (corporate loans) and reduces the probability of success of a marginal project A (and the average probability of success of type-A projects in the portfolio), since $\frac{d x_{A}^{*}}{d k_{B}}>0$. Lemma 1 summarizes the two cases.

Lemma 1. When banks are not financially constrained, investments and riskiness of loans in portfolios $A$ and $B$ are independent of each other. When the supply of bank funding is limited, investment decisions become interdependent. A higher capital requirement for one loan portfolio increases investment and riskiness of loans in the other portfolio.

Changes in risk sentiment and bank investment choices. We now demonstrate how changes in the risk sentiment among banks (and its creditors) can cause a switch of our simple economy from case I to case II. Suppose that the parameter $\theta$ driving the success probability of projects $\mathrm{A}$ and $\mathrm{B}$ can take one of two values, $\theta^{L}$ and $\theta^{H}$, with $\theta^{L}<\theta^{H}$. A high value of $\theta$ could be interpreted as reflecting the bad states of the world, and a low value as reflecting good aggregate economic conditions. Additionally, before investing in projects A and B, bank managers and bank creditors observe a signal $\hat{\theta} \in\left\{\hat{\theta}^{H}, \hat{\theta}^{L}\right\}$ about the true value of $\theta$. For simplicity we consider $\hat{\theta}$ to be a perfect signal, but in principle it could be associated with some 
error without affecting the results.

It is straightforward do demonstrate that with a time-varying $\theta$, the following Lemma holds 24

Lemma 2. Bank investments in portfolios $A$ and $B$ decline in $\theta$. Define $\bar{\theta}$ as

$$
\bar{\theta}=\frac{r_{A}-1-k_{A}\left(r_{K}-1\right)}{r_{A} I}+\frac{r_{B}-1-k_{B}\left(r_{K}-1\right)}{r_{B} I} .
$$

If $\theta^{L}<\bar{\theta}<\theta^{H}$, the resource constraint binds in good states of the world and it does not bind in the bad states of the world. As a result i) bank credit is procyclical, and ii) a rise in capital requirements for one portfolio leads to an increase in the size of lending and in the riskiness of loans in the other portfolio only in the good states of the world.

\section{Conclusions}

We contribute to the literature on spillovers and leakages from financial regulations by providing evidence of leakages from household sector-specific macroprudential regulations to corporate borrowers. We document leakages in terms of the volume of new bank credit to the corporate sector and in terms of the risk profile of credit allocated to corporate firms.

First, using bank-level data on loan volumes we show that after an unexpected tightening of household-specific MaPPs during credit expansions, banks with higher exposures to residential mortgages experience much higher corporate loan growth compared to banks which are less exposed to residential mortgages. In other words, leakages from sector-specific MaPPs are higher for banks more affected by the regulations.

Next, we construct three country-level measures of the riskiness of corporate credit allocation for a range of advanced and emerging economies, using firm-level data. Consistently across the three measures, we find that a tightening of household-specific macroprudential tools increases the riskiness of corporate credit allocation during credit expansions. The effects are economically meaningful: an unexpected tightening in the household-specific restrictions increases the credit riskiness measure by an average of 10 percent when the credit to GDP ratio grows at a rate one standard deviation above its mean. When replacing our measures of riskiness of corporate credit allocation with the changes in bank lending standards reported in loan officer surveys, the results indicate that the leakages from household-specific macroprudential policy actions might be particularly pronounced for large corporates, while actually tightening lending standards for SMEs. This further corroborates our hypothesis that as regulations start binding in household sector, the riskiness profile of corporate borrowers deteriorates.

\footnotetext{
${ }^{24}$ Another channel through which better economic outlook could affect the bindness of the resource constraint for banks is a time-varying rate of return on equity $r_{K}$. Empirically it is found to be lower during economic upswings, and to increase during downturns (see e.g. Yang and Tsatsaronis (2012)).
} 
Overall, our paper provides evidence that the cross-sectoral leakages from macroprudential policies might be quantitatively important. Thus, such effects should be considered by the policymakers deciding between broad-based and sector-specific macroprudential policy tools. In particular, our results support early policy interventions, i.e. during the early phase of the credit cycle, when sectoral leakages are growing but likely to be still low. To avoid large and unwanted leakage effects, timely monitoring of vulnerabilities and riskiness in both household and corporate sectors is key too. For the corporate sector, our results suggest that information on the distribution of the firms by size in bank loan portfolios might be relevant for assessing the size of potential leakage effects. While an alternative way to address the leakages we identify would be to design macroprudential tools explicitly for the corporates, so far this has been very difficult to implement in practice, due to heterogeneity of business models across firms.

\section{REFERENCES}

Acharya, Viral V., Katharina Bergant, Matteo Crosignani, Tim Eisert and Fergal McCann (2020), 'The anatomy of the transmission of macroprudential policies', IMF Working Paper $20 / 58$.

Acharya, Viral V., Tim Eisert, Christian Eufinger and Christian W. Hirsch (2019), 'Whatever it takes: The real effects of unconventional monetary policy', Review of Financial Studies 32(9), 3366-3411.

Adelino, Manuel, Antoinette Schoar and Felipe Severino (2016), 'Loan Originations and Defaults in the Mortgage Crisis: The Role of the Middle Class', The Review of Financial Studies 29(7), 1635-1670.

Ahnert, Toni, Kristin Forbes, Christian Friedrich and Dennis Reinhardt (2020), 'Macroprudential fx regulations: Shifting the snowbanks of fx vulnerability?', Journal of Financial Economics, forthcoming .

Aiyar, Shekhar, Charles W. Calomiris and Tomasz Wieladek (2014), 'Does macro-prudential regulation leak? evidence from a UK policy experiment', Journal of Money, Credit and Banking 46(s1), 181-214.

Akinci, Ozge and Jane Olmstead-Rumsey (2018), 'How effective are macroprudential policies? an empirical investigation', Journal of Financial Intermediation 33, 33 - 57.

Alam, Zohair, Adrian Alter, Jesse Eiseman, Gaston Gelos, Heedon Kang, Machiko Narita, Erlend Nier and Naixi Wang (2019), 'Digging deeper - evidence on the effects of macroprudential policies from a new database', IMF Working Paper No. 19/66. 
Araujo, Juliana D., Manasa Patnam, Adina Popescu, Fabian Valencia and Weijia Yao (2020), 'Effects of macroprudential policy: Evidence from over 6,000 estimates', IMF Working Paper No. 20/67.

Auer, Raphael and Steven Ongena (2016), 'The countercyclical capital buffer and the composition of bank lending', BIS Working Paper No. 593 .

Ayyagari, Meghana, Thorsten Beck and Maria Soledad Martinez-Peria (2018), 'The micro impact of macroprudential policies: Firm-level evidence', IMF Working Paper 18/267 .

Bahaj, Saleem, Angus Foulis, Gabor Pinter and Paolo Surico (2019), 'Employment and the collateral channel of monetary policy', Bank of England working papers 827.

Bengui, Julien and Javier Bianchi (2018), 'Macroprudential policy with leakages', Federal Reserve Bank of Minneapolis Working Paper 754.

Brandão Marques, Luis, Gaston Gelos, Machiko Narita and Erlend Nier (2020), 'Leaning against the wind: A cost-benefit analysis for an integrated policy framework', IMF Working Paper No. 20/123 .

Brandão Marques, Luis, Qianying Chen, Claudio Raddatz, Jérôme Vandenbussche and Peichu Xie (2019), 'The riskiness of credit allocation and financial stability', IMF Working Paper No. 19/207.

Cerutti, Eugenio, Stijn Claessens and Luc Laeven (2017), 'The use and effectiveness of macroprudential policies: New evidence', Journal of Financial Stability 28, 203-224.

Cizel, Janko, Jon Frost, Aerdt Houben and Peter Wierts (2019), 'Effective macroprudential policy: Cross-sector substitution from price and quantity measures', Journal of Money, Credit and Banking 51, 1209-1235.

Danisewicz, Piotr, Dennis Reinhardt and Rhiannon Sowerbutts (2017), 'On a tight leash: Does bank organizational structure matter for macroprudential spillovers?', Journal of International Economics 109, 174 - 194.

Forbes, Kristin and Michael Klein (2015), 'Pick Your Poison: The Choices and Consequences of Policy Responses to Crises', IMF Economic Review 63, 197-237.

Gelos, Gaston and Alejandro Werner (2002), 'Financial liberalization, credit constraints, and collateral: investment in the Mexican manufacturing sector', Journal of Development Economics 67(1), 1-27.

Greenwood, Robin and Samuel G. Hanson (2013), 'Issuer Quality and Corporate Bond Returns', The Review of Financial Studies 26(6), 1483-1525. 
Houston, Joel F., Chen Lin and Yue Ma (2012), 'Regulatory arbitrage and international bank flows', The Journal of Finance 67(5), 1845-1895.

International Monetary Fund (2017), 'Are countries loosing control of domestic financial conditions?', Global Financial Stability Report: Chapter 3 (April).

International Monetary Fund (2018), 'The riskiness of credit allocation: A source of financial vulnerability?', Global Financial Stability Report: Chapter 2 (April).

Jordá, Óscar (2005), 'Estimation and inference of impulse responses by local projections', American Economic Review 95(1), 161-182.

Kirti, Divya (2020), 'Lending standards and output growth (July, 2018)', ESRB: Working Paper Series No. 2018/79.

Koop, Gary and Dimitris Korobilis (2014), 'A new index of financial conditions', European Economic Review 71, 101-116.

Kuttner, Kenneth N. and Ilhyock Shim (2016), 'Can non-interest rate policies stabilize housing markets? evidence from a panel of 57 economies', Journal of Financial Stability 26, 31-44.

Lian, Chen and Yueran Ma (2020), 'Anatomy of corporate borrowing constraints', Quarterly Journal of Economics, forthcoming .

Ongena, Steven, Alexander Popov and Gregory F. Udell (2013), 'When the cat's away the mice will play: Does regulation at home affect bank risk-taking abroad?', Journal of Financial Economics 108(3), 727 - 750 .

Temesvary, Judit (2018), 'The role of regulatory arbitrage in U.S. banks' international flows: Bank-level evidence', Economic Inquiry 56(4), 2077-2098.

Wu, Jing Cynthia and Fan Dora Xia (2016), 'Measuring the macroeconomic impact of monetary policy at the zero lower bound', Journal of Money, Credit and Banking 48(2-3), 253-291.

Yang, Jing and Kostas Tsatsaronis (2012), 'Bank stock returns, leverage and the business cycle', BIS Quarterly Review March. 


\section{A Appendix}

\section{A.1 Data: sources and definitions}

Table (A1) Variables and data sources.

\begin{tabular}{|c|c|c|}
\hline Variable & Description & Source \\
\hline $\begin{array}{l}\text { total assets, total debt, } \\
\text { EBITDA, Debt Interest Expense }\end{array}$ & $\begin{array}{l}\text { balance sheet variables needed to compute } \\
\text { the measures of corporate credit riskiness }\end{array}$ & Datastream \\
\hline 3-month money market rate & measure of domestic fin. conditions & Datastream \\
\hline MSCI VIX, U.S. policy rates & measures of global financial conditions & Datastream \\
\hline global shadow rate & shadow US policy rate & Wu and Xia (2016) \\
\hline macroprudential policy indices & $\begin{array}{l}M a P P^{H H} \text { : a sum of indicators } L T V, D S T I, \\
\text { LoanR } R^{H H} ; M a P P^{B C}: \text { a sum of indicators } \\
\text { Capital Gen }, \text { Capital Corp Conservation, } \\
C C B, L C G^{\text {Gen }}, L C G^{\text {Corp }}, \text { LoanR, LoanR } \\
\end{array}$ & $\begin{array}{l}\text { iMaPP database, } \\
\text { Alam et al. (2019) }\end{array}$ \\
\hline $\begin{array}{l}\text { real GDP } \\
\text { exchange rate against USD }\end{array}$ & growth rates & WEO database \\
\hline real house price index & growth rate & IMF \\
\hline Financial Conditions Index (FCI) & $\begin{array}{l}\text { index based on: corporate, interbank, } \\
\text { sovereign spreads, term spreads, long-term } \\
\text { interest rates, equity return volatility, } \\
\text { equity and house price returns, market share } \\
\text { of the financial sector, and credit growth }\end{array}$ & IMF (2017) \\
\hline $\begin{array}{l}\text { credit to domestic nonfinancial } \\
\text { private sector, and to domestic } \\
\text { NFCs, NFC bonds outstanding }\end{array}$ & $\begin{array}{l}\text { ratios relative to GDP, } \\
\text { growth rates }\end{array}$ & BIS \\
\hline corporate bond to credit ratio & $\begin{array}{l}\text { ratio of NFC bonds outstanding } \\
\text { to credit to nonfinancial corporates, } \\
\text { four-quarter moving average }\end{array}$ & BIS \\
\hline Capital Account Openness & Chin and Ito's Index & $\begin{array}{l}\text { IMF AREAER } \\
\text { database }\end{array}$ \\
\hline average LTV limit & $\begin{array}{c}\text { simple average of regulatory LTV limits } \\
\text { on all existing loan categories; } \\
\text { when a country does not have LTV limits, } \\
\text { the value is set at } 100\end{array}$ & $\begin{array}{l}\text { iMaPP database } \\
\text { Alam et al. }(2019)\end{array}$ \\
\hline $\begin{array}{l}\text { bank lending standards } \\
\text { from loan officer surveys }\end{array}$ & $\begin{array}{c}\text { measure of a change in lending standards: } \\
\text { a positive value indicates a tightening, } \\
\text { a negative value-an easing }\end{array}$ & Haver Analytics \\
\hline $\begin{array}{l}\text { residential mortgage loans, } \\
\text { corporate and commerical loans }\end{array}$ & $\begin{array}{l}\text { bank balance sheet variables needed to } \\
\text { compute the CLG indicator }\end{array}$ & Fitch Connect \\
\hline
\end{tabular}

\section{A.2 Construction of macroprudential policy shocks}

We proceed in two steps. First, for both MaPP indicators, $M a P^{H H}$ and $M a P P^{B C}$, we estimate the following ordered probit regression:

$$
M \tilde{a} P_{i, t}^{j}=\alpha_{i}+\mu_{t}+\beta_{1} X_{i, t-1}+\beta_{2} G D P_{i, t}^{f}+\epsilon_{i, t},
$$


where $M a \tilde{P} P_{i, t}^{j}$ is a categorical macroprudential indicator, with $j=\{H H, B C\}$, which takes values $\{-2,-1,0,1,2\}$ if, in net terms, there were more than one loosening actions, one loosening action, no change, one tightening action, or more than two tightening actions in the quarter $t$ in country $i$, respectively. The vector $X_{i, t-1}$ consists of the following control variables: year-onyear real GDP growth, quarter-on-quarter growth in credit to GDP ratio, financial development index (FDI), Chinn and Ito's capital account openness index, quarter-on-quarter USD bilateral exchange rate change and quarter-on-quarter house price growth. All variables are lagged one quarter, except for the FDI and the capital account openness indices-which are only available at annual frequency and thus we include a fourth lag of the two variables. The variable $G D P_{i, t}^{f}$ stands for one-year ahead Consensus forecast of real GDP growth.

The policy shock is then recovered as the difference between the actual value of the macroprudential indicator and its estimated conditional expectation:

$$
\hat{\varepsilon}_{i, t}^{j}=M \tilde{a} P_{i, t}^{j}-\sum_{k=-2}^{2} \hat{p}_{k}\left(X_{i, t-1}, G D P_{i, t}^{f}\right) k,
$$

where $\hat{p}_{k}\left(X_{i, t-1}, G D P_{i, t}^{f}\right)$ is the estimated probability of $M a \tilde{P} P_{i, t}^{j}=k$, with $k \in\{-2,-1,0,1,2\}$ conditional on the right-hand side variables of equation A.1.

The first two columns of the Table A2 present results for the specification (A.1). The last two columns show an alternative specification, in which growth of the credit to GDP ratio is replaced by by bank credit growth in the regression for the $M a \tilde{P P} P^{H H}$, and by bank credit growth and growth in nonfinancial corporates bonds-to-GDP ratio in the regression for the $M a \tilde{P} P B C$. Additionally, in the regression for the $M a \tilde{P P}^{H H}$, we add a domestic financial conditions index, and in the regressions for $M a \tilde{P} P^{B C}$-the 3-month money market rate (the results for $M a \tilde{P} P^{B C}$ are unchanged when including the FCI instead of the short-term rate albeit the number of observations declines further in that case). Given the reduced number of observations when controlling for bank NFC bond issuance, we choose (A.1) as our preferred specification, but the results remain unchanged when using MaPP shocks derived using specifications in columns (3)-(4), as shown in Table A3. 
Table (A2) Macroprudential shocks: first-stage regressions

\begin{tabular}{|c|c|c|c|c|}
\hline VARIABLES & $\begin{array}{c}(1) \\
M \tilde{a} P P^{B C}\end{array}$ & $\begin{array}{c}(2) \\
M \tilde{a} P P^{H H}\end{array}$ & $\begin{array}{c}(3) \\
M \tilde{a} P P^{B C}\end{array}$ & $\begin{array}{c}(4) \\
M \tilde{a P P}\end{array}$ \\
\hline$G D P^{f}$ & $\begin{array}{l}0.142^{*} \\
(0.085)\end{array}$ & $\begin{array}{c}0.156^{* *} \\
(0.064)\end{array}$ & $\begin{array}{l}0.250^{*} \\
(0.144)\end{array}$ & $\begin{array}{c}0.082 \\
(0.090)\end{array}$ \\
\hline$\Delta G D P_{t-1}$ & $\begin{array}{l}-2.434 \\
(2.899)\end{array}$ & $\begin{array}{l}-0.504 \\
(2.086)\end{array}$ & $\begin{array}{l}-1.763 \\
(4.756)\end{array}$ & $\begin{array}{l}-2.909 \\
(2.581)\end{array}$ \\
\hline$\Delta_{q}$ Credit $_{t-1}$ & $\begin{array}{l}-1.572 \\
(2.212)\end{array}$ & $\begin{array}{c}1.137 \\
(1.678)\end{array}$ & & \\
\hline$\Delta_{q} E R_{t-1}$ & $\begin{array}{l}-1.407 \\
(1.908)\end{array}$ & $\begin{array}{l}-1.775 \\
(1.393)\end{array}$ & $\begin{array}{l}-2.864 \\
(2.576)\end{array}$ & $\begin{array}{l}-1.216 \\
(1.673)\end{array}$ \\
\hline CAOpen s $_{t-1}$ & $\begin{array}{c}0.139 \\
(0.170)\end{array}$ & $\begin{array}{c}0.022 \\
(0.112)\end{array}$ & $\begin{array}{c}0.142 \\
(0.261)\end{array}$ & $\begin{array}{c}0.088 \\
(0.145)\end{array}$ \\
\hline$F D I_{t-1}$ & $\begin{array}{c}-0.581 \\
(1.622)\end{array}$ & $\begin{array}{c}-2.397^{* *} \\
(1.104)\end{array}$ & $\begin{array}{l}-0.054 \\
(2.187)\end{array}$ & $\begin{array}{c}-4.183^{* * *} \\
(1.486)\end{array}$ \\
\hline$\Delta_{q} H P I_{t-1}$ & $\begin{array}{c}1.382 \\
(2.376)\end{array}$ & $\begin{array}{c}0.994 \\
(1.802)\end{array}$ & $\begin{array}{l}-0.306 \\
(3.551)\end{array}$ & $\begin{array}{c}1.596 \\
(2.268)\end{array}$ \\
\hline$\Delta_{q}$ BankCredit $_{t-1}$ & & & $\begin{array}{l}5.010^{*} \\
(2.571)\end{array}$ & $\begin{array}{c}0.635 \\
(1.633)\end{array}$ \\
\hline$\Delta_{q} N F C B$ Bond $s_{t-1}$ & & & $\begin{array}{c}-0.197 \\
(0.399)\end{array}$ & \\
\hline nominalrate $_{t-1}$ & & & $\begin{array}{l}-0.032 \\
(0.064)\end{array}$ & \\
\hline$F C I_{t-1}$ & & & & $\begin{array}{c}-0.353^{* * *} \\
(0.132)\end{array}$ \\
\hline Observations & 2,861 & 2,861 & 1,718 & 1,914 \\
\hline Country FE & Yes & Yes & Yes & Yes \\
\hline Time FE & Yes & Yes & Yes & Yes \\
\hline
\end{tabular}

Note: Additional variables $-G D P^{f}$ is the one-year ahead GDP forecasts from Consensus Forecasts, CAOpen is the Chinn Ito's Capital Account Index, FDI is the financial development index, $\Delta_{q} H P I$ is the qoq real house price growth, $\Delta_{q}$ BankCredit is qoq growth of real bank credit to the domestic private nonfinancial sector, $\Delta_{q} N F C B o n d s$ is the qoq growth of the non-financial corporate bonds to GDP ratio, nominalrate stands for the 3 -month money market rate. 
Table (A3) Baseline results with macroprudential shocks derived using alternative first-stage regression specification

\begin{tabular}{|c|c|c|c|}
\hline VARIABLES & $\begin{array}{c}(1) \\
\text { TDTA }\end{array}$ & $\begin{array}{l}(2) \\
\text { ICR }\end{array}$ & $\begin{array}{c}(3) \\
\text { TDtE }\end{array}$ \\
\hline dependent variable, $t-1$ & $\begin{array}{c}0.471^{* * *} \\
(0.052)\end{array}$ & $\begin{array}{c}0.313^{* * *} \\
(0.052)\end{array}$ & $\begin{array}{c}0.358^{* * *} \\
(0.043)\end{array}$ \\
\hline $\bar{\varepsilon}_{t-1}^{H H}$ & $\begin{array}{l}-0.002 \\
(0.043)\end{array}$ & $\begin{array}{c}-0.091^{*} \\
(0.046)\end{array}$ & $\begin{array}{c}-0.118^{* *} \\
(0.054)\end{array}$ \\
\hline $\bar{\varepsilon}_{t-1}^{B C}$ & $\begin{array}{l}0.011 \\
(0.061)\end{array}$ & $\begin{array}{l}0.038 \\
(0.065)\end{array}$ & $\begin{array}{c}0.042 \\
(0.088)\end{array}$ \\
\hline $\bar{\varepsilon}_{t-1}^{H H} \times \Delta$ Credit $_{t-1}$ & $\begin{array}{l}0.014^{*} \\
(0.007)\end{array}$ & $\begin{array}{l}0.018^{*} \\
(0.010)\end{array}$ & $\begin{array}{r}0.024^{* *} \\
(0.010)\end{array}$ \\
\hline $\bar{\varepsilon}_{t-1}^{B C} \times \Delta$ Credit $_{t-1}$ & $\begin{array}{l}-0.013 \\
(0.010)\end{array}$ & $\begin{array}{l}-0.023 \\
(0.019)\end{array}$ & $\begin{array}{l}-0.013 \\
(0.014)\end{array}$ \\
\hline$\Delta$ Credit $_{t-1}$ & $\begin{array}{c}0.013 \\
(0.009)\end{array}$ & $\begin{array}{c}0.008 \\
(0.011)\end{array}$ & $\begin{array}{l}0.019^{*} \\
(0.011)\end{array}$ \\
\hline$\Delta G D P_{t-1}$ & $\begin{array}{c}0.053^{* * *} \\
(0.013)\end{array}$ & $\begin{array}{c}0.032^{* *} \\
(0.015)\end{array}$ & $\begin{array}{c}0.062^{* * *} \\
(0.019)\end{array}$ \\
\hline$\Delta_{q} E R_{t-1}$ & $\begin{array}{c}-0.018^{* *} \\
(0.006)\end{array}$ & $\begin{array}{c}0.002 \\
(0.006)\end{array}$ & $\begin{array}{l}-0.001 \\
(0.007)\end{array}$ \\
\hline Observations & 849 & 849 & 841 \\
\hline Number of Countries & 18 & 18 & 18 \\
\hline Adjusted R-squared & 0.378 & 0.191 & 0.249 \\
\hline Country FE & Yes & Yes & Yes \\
\hline Time FE & Yes & Yes & Yes \\
\hline Interaction & Yes & Yes & Yes \\
\hline
\end{tabular}

Note: Refer to Table 5 for variable descriptions. The macroprudential shocks are derived as residuals from regressions in columns (3)-(4) of the Table A2.

\section{A.3 Macroprudential policies, household lending and house price growth}

For completeness, we also show that household-specific macroprudential policies are effective in achieving their frequent operational targets i.e. affecting growth of credit to the household sector and growth of house prices. For this purpose we regress 1) quarter-on-quarter growth in the household credit to GDP ratio $\left(\Delta_{q} H H C r e d i t\right)$, and 2) quarter-on-quarter real house price growth $\left(\Delta_{q} H P I\right)$ on household-specific macroprudential policy shocks and their interaction with the lagged household credit to GDP growth, while controlling for real GDP growth, exchange rate appreciation against USD, past growth in household credit to GDP ratio and domestic 3-month money market rate. Table A4 presents the results. It shows that an unexpected household-specific MaPP tightening in the past four quarters reduces house price growth and growth of credit to the household sector when credit growth has been rapid in the recent past. 
Table (A4) Impact of household-specific macroprudential policies on lending to households and house price growth

\begin{tabular}{|c|c|c|c|c|}
\hline VARIABLES & $\begin{array}{l}\text { (1) } \\
\text { HPI }\end{array}$ & $\begin{array}{l}(2) \\
\text { HPI }\end{array}$ & $\begin{array}{c}(3) \\
\text { HH Credit }\end{array}$ & $\begin{array}{c}(4) \\
\text { HH Credit }\end{array}$ \\
\hline $\bar{\varepsilon}_{t-1}^{H H}$ & $\begin{array}{c}0.057 \\
(0.064)\end{array}$ & $\begin{array}{c}0.049 \\
(0.062)\end{array}$ & $\begin{array}{c}0.071 \\
(0.046)\end{array}$ & $\begin{array}{c}0.067 \\
(0.052)\end{array}$ \\
\hline $\bar{\varepsilon}_{t-1}^{H H} \times \Delta H$ HCredit $t_{t-1}$ & $\begin{array}{c}-0.031^{* *} \\
(0.013)\end{array}$ & $\begin{array}{c}-0.031^{* *} \\
(0.013)\end{array}$ & $\begin{array}{c}-0.078^{* * *} \\
(0.013)\end{array}$ & $\begin{array}{c}-0.077^{* * *} \\
(0.012)\end{array}$ \\
\hline nominalrate $_{t-1}$ & & $\begin{array}{c}-0.135^{* * * *} \\
(0.046)\end{array}$ & & $\begin{array}{c}-0.244^{* * *} \\
(0.068)\end{array}$ \\
\hline$\Delta_{q} H P I_{t-1}$ & $\begin{array}{c}0.318^{* * *} \\
(0.065)\end{array}$ & $\begin{array}{c}0.308^{* * *} \\
(0.066)\end{array}$ & & \\
\hline$\Delta_{q} H$ HCredit $t_{-1}$ & $\begin{array}{c}0.054^{* * *} \\
(0.009)\end{array}$ & $\begin{array}{c}0.050^{* * *} \\
(0.009)\end{array}$ & $\begin{array}{c}0.125^{* * *} \\
(0.026)\end{array}$ & $\begin{array}{c}0.116^{* * *} \\
(0.024)\end{array}$ \\
\hline$\Delta G D P_{t-1}$ & $\begin{array}{c}0.162^{* * *} \\
(0.045)\end{array}$ & $\begin{array}{c}0.135^{* * *} \\
(0.046)\end{array}$ & $\begin{array}{c}0.063 \\
(0.084)\end{array}$ & $\begin{array}{c}0.009 \\
(0.060)\end{array}$ \\
\hline$\Delta_{q} E R_{t-1}$ & $\begin{array}{l}0.045 \\
(0.028)\end{array}$ & $\begin{array}{c}0.038 \\
(0.024)\end{array}$ & $\begin{array}{c}0.079^{* * *} \\
(0.023)\end{array}$ & $\begin{array}{c}0.063^{* * *} \\
(0.016)\end{array}$ \\
\hline Observations & 1,331 & 1,322 & 1,331 & 1,322 \\
\hline Number of Countries & 23 & 23 & 23 & 23 \\
\hline Adjusted R-squared & 0.275 & 0.281 & 0.370 & 0.391 \\
\hline Dom FCI & No & Yes & No & Yes \\
\hline Country FE & Yes & Yes & Yes & Yes \\
\hline Time FE & Yes & Yes & Yes & Yes \\
\hline
\end{tabular}

Note: Additional variables- $\Delta_{q} H H C r e d i t_{t-1}$ is the quarter-on-quarter growth in the household credit to GDP ratio, $\Delta H_{H C r e d i t} t_{t-1}$ is the year-on-year growth in the household credit to GDP ratio. $\Delta_{q} H P I$ is the quarteron-quarter real house price growth.

\section{A.4 Deriving impact of macroprudential policies on corporate credit riski- ness using local projections}

The results are robust to using the local projections in Jordá (2005). To run the local projections, we consider the following regression at horizons $h=1,2 . .8$ :

$$
\begin{aligned}
C C_{i, t+h}^{s} & =\alpha_{i}^{h}+\sum_{k=0}^{1} \beta_{1, k}^{h} \varepsilon_{i, t-k}^{H H}+\sum_{k=0}^{1} \beta_{2, k}^{h} \varepsilon_{i, t-k}^{B C}+\beta_{3}^{h} \varepsilon_{i, t}^{H H} \times \Delta \text { Credit }_{i, t}+\beta_{4}^{h} \varepsilon_{i, t}^{B C} \times \Delta \text { Credit }_{i, t}+ \\
& +\sum_{k=0}^{1} \beta_{5, k}^{h} \Delta \text { Credit }_{i, t-k}+\sum_{k=0}^{1} \beta_{6, k}^{h} \Delta E R_{i, t-k}+\sum_{k=0}^{1} \beta_{7, k}^{h} \Delta G D P_{i, t-k}+\epsilon_{i, t+h},
\end{aligned}
$$

where all variables are defined as in Section ??. Figure 6 shows, for each of the three credit riskiness measures, the coefficients on the interaction term $\varepsilon_{i, t}^{H H} \times \Delta C r e d i t_{i, t}$ at different horizons. For all the three measures, the interaction term is broadly positive and-at some horizonspositive and statistically significant. 
Figure (6) Responses of corporate credit riskiness measures to household-specific macroprudential policy shocks: local projections.

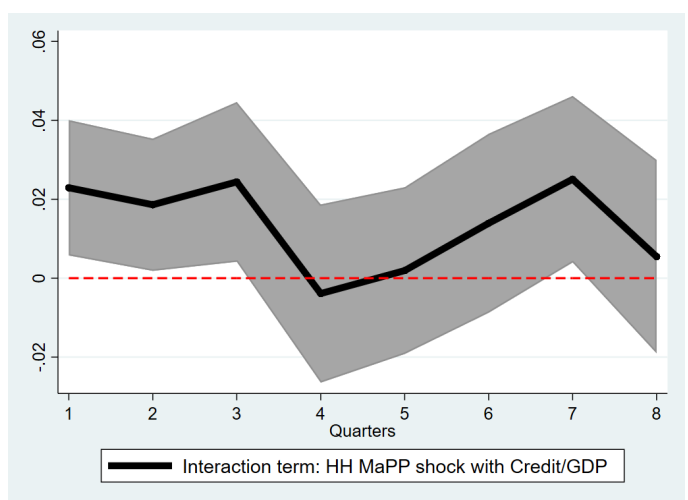

(a) TDTA

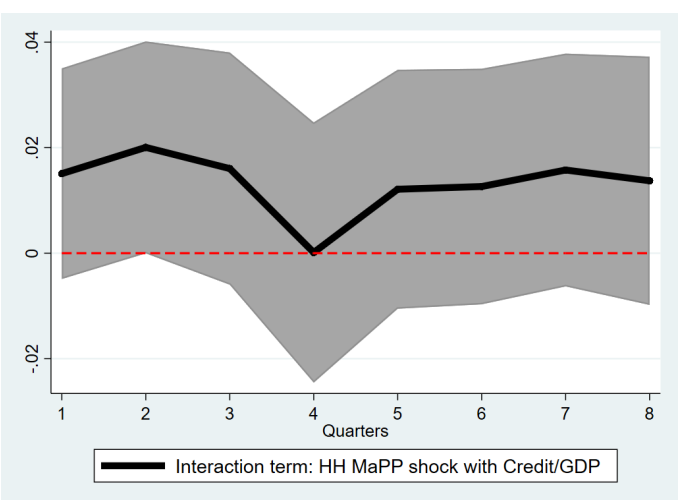

(b) TDtE

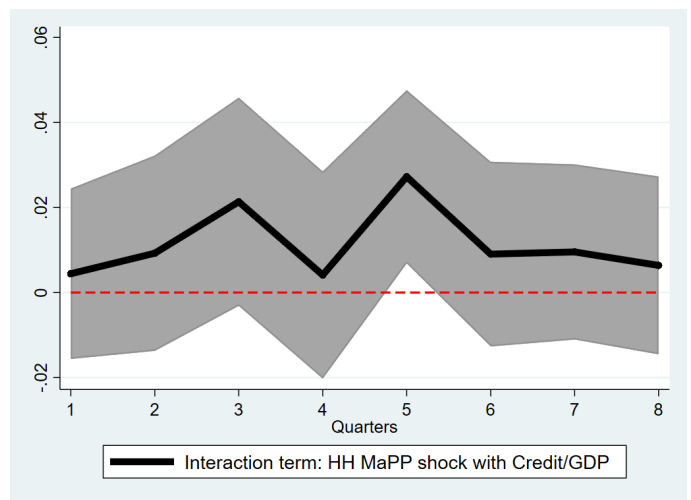

(c) ICR

Note: The figure plots the coefficient $\beta_{3}^{h}$ from equation A.3 for $h=1,2, \ldots 8$, for the three measures of the riskiness of corporate credit allocation (TDTA,ICR and TDtE). Grey areas correspond to 90 percent confidence intervals.

\section{A.5 Results with MaPP actions}

The results are robust to using macroprudential policy actions rather than shocks. We replace the MaPP shocks in (3) and (4), with changes in policy actions using $M a P P^{H H(B C)}$ and their four-period sums $\left(M a P P_{\text {sum }}^{H H(B C)}\right)$ respectively. Table A5 below present the results for the baseline specifications. 
Table (A5) Baseline results using MaPP actions

\begin{tabular}{|c|c|c|c|c|c|c|}
\hline VARIABLES & $\begin{array}{c}(1) \\
\text { TDTA }\end{array}$ & $\begin{array}{c}(2) \\
\text { ICR }\end{array}$ & $\begin{array}{c}(3) \\
\text { TDtE }\end{array}$ & $\begin{array}{c}(4) \\
\text { TDTA }\end{array}$ & $\begin{array}{c}(5) \\
\text { ICR }\end{array}$ & $\begin{array}{c}(6) \\
\text { TDtE }\end{array}$ \\
\hline DependentVariable $e_{t-1}$ & $\begin{array}{c}0.529^{* * *} \\
(0.042)\end{array}$ & $\begin{array}{c}0.354^{* * *} \\
(0.035)\end{array}$ & $\begin{array}{c}0.406^{* * *} \\
(0.035)\end{array}$ & $\begin{array}{c}0.529 * * * \\
(0.042)\end{array}$ & $\begin{array}{c}0.349^{* * *} \\
(0.034)\end{array}$ & $\begin{array}{c}0.402^{* * *} \\
(0.035)\end{array}$ \\
\hline$M a P P^{H H}, \operatorname{Lag} 1$ & $\begin{array}{c}0.005 \\
(0.041)\end{array}$ & $\begin{array}{l}-0.064 \\
(0.043)\end{array}$ & $\begin{array}{c}-0.078^{*} \\
(0.042)\end{array}$ & & & \\
\hline$M a P P^{H H}$, Lag 2 & $\begin{array}{c}0.114^{* *} \\
(0.048)\end{array}$ & $\begin{array}{c}0.004 \\
(0.042)\end{array}$ & $\begin{array}{l}-0.023 \\
(0.054)\end{array}$ & & & \\
\hline$M a P P^{H H}$, Lag 3 & $\begin{array}{c}0.080 \\
(0.047)\end{array}$ & $\begin{array}{c}0.003 \\
(0.067)\end{array}$ & $\begin{array}{l}-0.012 \\
(0.058)\end{array}$ & & & \\
\hline$M a P P^{H H}$, Lag 4 & $\begin{array}{l}-0.003 \\
(0.043)\end{array}$ & $\begin{array}{l}0.067^{*} \\
(0.037)\end{array}$ & $\begin{array}{c}0.056 \\
(0.049)\end{array}$ & & & \\
\hline$\Delta$ Credit $_{t-1}$ & $\begin{array}{c}0.022^{* * *} \\
(0.005)\end{array}$ & $\begin{array}{c}0.017^{* * *} \\
(0.005)\end{array}$ & $\begin{array}{c}0.024^{* * *} \\
(0.005)\end{array}$ & $\begin{array}{c}0.022^{* * *} \\
(0.005)\end{array}$ & $\begin{array}{c}0.017^{* * * *} \\
(0.005)\end{array}$ & $\begin{array}{c}0.023^{* * *} \\
(0.004)\end{array}$ \\
\hline$\Delta G D P_{t-1}$ & $\begin{array}{c}0.015 \\
(0.018)\end{array}$ & $\begin{array}{c}0.015 \\
(0.012)\end{array}$ & $\begin{array}{l}0.032^{*} \\
(0.016)\end{array}$ & $\begin{array}{c}0.013 \\
(0.018)\end{array}$ & $\begin{array}{c}0.012 \\
(0.013)\end{array}$ & $\begin{array}{l}0.029^{*} \\
(0.016)\end{array}$ \\
\hline$\Delta_{q} E R_{t-1}$ & $\begin{array}{c}-0.013^{* * *} \\
(0.004)\end{array}$ & $\begin{array}{l}0.010 * \\
(0.005)\end{array}$ & $\begin{array}{c}0.005 \\
(0.005)\end{array}$ & $\begin{array}{c}-0.013^{* * *} \\
(0.004)\end{array}$ & $\begin{array}{l}0.009 * \\
(0.005)\end{array}$ & $\begin{array}{c}0.004 \\
(0.005)\end{array}$ \\
\hline$M a P P_{\text {sum }}^{H H}$ & & & & $\begin{array}{c}0.042^{* *} \\
(0.020)\end{array}$ & $\begin{array}{c}-0.021 \\
(0.027)\end{array}$ & $\begin{array}{l}-0.048 \\
(0.034)\end{array}$ \\
\hline$M a P P_{\text {sum }}^{B C}$ & & & & $\begin{array}{l}-0.023 \\
(0.056)\end{array}$ & $\begin{array}{c}0.009 \\
(0.051)\end{array}$ & $\begin{array}{c}0.028 \\
(0.052)\end{array}$ \\
\hline$M a P P_{\text {sum }}^{H H} \times \Delta$ Credit $_{t-1}$ & & & & $\begin{array}{c}0.005 \\
(0.005)\end{array}$ & $\begin{array}{c}0.012^{* *} \\
(0.005)\end{array}$ & $\begin{array}{c}0.014^{* * *} \\
(0.005)\end{array}$ \\
\hline$M a P P_{\text {sum }}^{B C} \times \Delta$ Credit $_{t-1}$ & & & & $\begin{array}{c}-0.009 \\
(0.006)\end{array}$ & $\begin{array}{c}-0.020^{*} \\
(0.010)\end{array}$ & $\begin{array}{l}-0.016 \\
(0.010)\end{array}$ \\
\hline Observations & 1,571 & 1,571 & 1,559 & 1,571 & 1,571 & 1,559 \\
\hline Number of Countries & 27 & 27 & 27 & 27 & 27 & 27 \\
\hline Adjusted R-squared & 0.419 & 0.156 & 0.235 & 0.419 & 0.160 & 0.237 \\
\hline Country FE & Yes & Yes & Yes & Yes & Yes & Yes \\
\hline Time FE & Yes & Yes & Yes & Yes & Yes & Yes \\
\hline Interaction & & & & Yes & Yes & Yes \\
\hline
\end{tabular}

Robust standard errors in parentheses

$* * * \mathrm{p}<0.01, * * \mathrm{p}<0.05, * \mathrm{p}<0.1$

Note: $M a P P^{H H(B C)}$ is the household-specific (broad-based or corporate-specific) MaPP policy action, $M a P P_{\text {sum }}^{H H(B C)}$ is the sum of policy actions in the past four quarters. 